\title{
Redox Reactions of Copper Complexes Formed with Different $\beta$ - amyloid Peptides and Their Neuropathalogical Relevance ${ }^{\dagger}$
}

\author{
Dianlu Jianga ${ }^{\mathrm{a}}$ Lijie Men $^{\mathrm{b}}$, Jianxiu Wang ${ }^{\mathrm{a}}$, Yi Zhang ${ }^{\mathrm{a}}$, Sara Chickenyen ${ }^{\mathrm{a}}$, Yinsheng Wang ${ }^{\mathrm{b}}$, \\ and Feimeng Zhou ${ }^{\mathrm{a}}{ }^{*}$ \\ aDepartment of Chemistry and Biochemistry, California State University, Los Angeles, Los \\ Angeles, California 90032, USA \\ bDepartment of Chemistry, University of California at Riverside, Riverside, California 92521, USA
}

\section{Abstract}

The binding stoichiometry between $\mathrm{Cu}(\mathrm{II})$ and the full-length $\beta$-amyloid $\mathrm{A} \beta(1-42)$ and the oxidation state of copper in the resultant complex were determined by electrospray ionizationFourier transform ion cyclotron resonance mass spectrometry (ESI-FTICR-MS) and cyclic voltammetry. The same approach was extended to the copper complexes of $A \beta(1-16)$ and $A \beta(1-$ 28). A stoichiometric ratio of 1:1 was directly observed and the oxidation state of copper was deduced to be $2+$ for all the complexes and residues tyrosine- 10 and methionine- 35 are not oxidized in the $\mathrm{A} \beta(1-42)-\mathrm{Cu}(\mathrm{II})$ complex. The stoichiometric ratio remains the same in the presence of more than 10 fold excess of $\mathrm{Cu}(\mathrm{II})$. Redox potentials of the sole tyrosine residue and the $\mathrm{Cu}$ (II) center were determined to be ca. $0.75 \mathrm{~V}$ and $0.08 \mathrm{~V}$ vs. $\mathrm{Ag} / \mathrm{AgCl}$ (or $0.95 \mathrm{~V}$ and $0.28 \mathrm{~V}$ vs. normal hydrogen electrode (NHE)), respectively. More importantly, for the first time, A $\beta$ $\mathrm{Cu}(\mathrm{I})$ complex has been generated electrochemically and was found to catalyze the reduction of oxygen to produce hydrogen peroxide. The voltammetric behaviors of the three $\mathrm{A} \beta$ segments suggest that diffusion of oxygen to the metal center can be affected by the length and hydrophobicity of the $\mathrm{A} \beta$ peptide. The determination and assignment of the redox potentials clarify some misconceptions in the redox reactions involving $A \beta$ and provide new insight into the possible roles of redox metal ions in the Alzheimer's disease (AD) pathogenesis. In cellular environments, the reduction potential of the $\mathrm{A} \beta-\mathrm{Cu}(\mathrm{II})$ complex is sufficiently low to react with antioxidants (e.g., ascorbic acid) and cellular redox buffers (e.g., glutathione), and the $\mathrm{A} \beta-\mathrm{Cu}(\mathrm{I})$ complex produced could subsequently reduce oxygen to form hydrogen peroxide via a catalytic cycle. Using voltammetry, the $\mathrm{A} \beta-\mathrm{Cu}$ (II) complex formed in solution was found to be readily reduced by ascorbic acid. Hydrogen peroxide produced, in addition to its role in damaging DNA, protein, and lipid molecules, can also be involved in the further consumption of antioxidants, causing their depletion in neurons and eventually damaging the neuronal defense system. Another possibility is that $\mathrm{A} \beta-\mathrm{Cu}(\mathrm{II})$ could react with species involved in the cascade of electron transfer events of mitochondria and might potentially side-track the electron transfer processes in the respiratory chain, leading to mitochondrial dysfunction.

\footnotetext{
$\dagger$ This work was supported by research grants (Grant No. GM 08101 to F. Z. and R01 CA101864 to Y. W.) and partially supported by the NIH-RIMI Program at California State University-Los Angeles (P20 MD001824-01).

*zhou@calstatela.edu.

Supporting Information Available: ESI-FTICR mass spectra of $A \beta(1-28)$ and $A \beta(1-42)$, an linear-ion trap mass spectrum of the $\mathrm{A} \beta(1-42)-\mathrm{Cu}(\mathrm{II})$ complex, a voltammogram of $\mathrm{Cu}(\mathrm{II})$ in a thoroughly deaerated solution, voltammograms of ascorbic acid in the presence of $\mathrm{A} \beta(1-42)-\mathrm{Cu}(\mathrm{II})$, and a table showing the relation between the $\mathrm{A} \beta(1-42)-\mathrm{Cu}(\mathrm{II})$ complex and the molar ratio of $\mathrm{Cu}(\mathrm{II})$ and A $\beta(1-42)$ are included in the Supporting Information. This material is available free of charge via the Internet at http://pubs.acs.org

$\dagger$ This work was supported by research grants (Grant No. GM 08101 to F. Z. and R01 CA101864 to Y. W.) and partially supported by the NIH-RIMI Program at California State University-Los Angeles (P20 MD001824-01).
} 
Alzheimer's disease (AD) is a progressive neurodegenerative disorder underscored by the appearance of senile plaques in disease-inflicted brains. The major components in senile plaques are peptides containing 39-43 amino acid residues (amyloid- $\beta$ or A $\beta$ peptides) generated from proteolytic cleavage of the amyloid precursor protein (APP) by $\beta$ - and $\gamma$ secretases $(1,2)$. Such findings $(2,3)$ led to the hypothesis that deposition of $A \beta$ fibrils and other aggregates is responsible for neuronal cell loss (4). However, how $\beta$-amyloid associates with the $\mathrm{AD}$ pathogenesis remains unclear.

Other characteristics in AD-affected brains include the enhanced level of oxidative stress manifested by extensive oxidation of proteins (5-7) and DNA (8-10), unusually high levels of metals (e.g., copper, zinc and iron) present in the senile plaques, and a decline of polyunsaturated fatty acids $(11,12)$ coupled with increased lipid peroxidation $(13-15)$. On the basis of the amyloid hypothesis and the existence of oxidative stress, Butterfield and coworkers (15) proposed a model to account for neurodegeneration in AD, viz., $\beta$-amyloid peptide-initiated oxidative stress and neurotoxicity. The aggregated amyloid peptide, perhaps in concert with complexed redox metal ions, produces free radicals and triggers a cascade of events, which include, but are not limited to, protein oxidation, lipid peroxidation, and cellular dysfunction. All of these detrimental processes result in death of neurons (15).

Together with these pathological characteristics, intracellular lesions, including impairment of mitochondrial energy metabolism, have also been purported to be a cause of the AD development $(9,10,16,17)$. In addition, impaired energy metabolism and altered cytochrome $c$ oxidase activity are among the earliest detectable defects in AD (18-21). Recently, the linkage between mitochondrial dysfunction and $\mathrm{A} \beta$ peptides has been suggested by Deshpande et al. (22) who showed that, after treatment of neuronal cells with $\mathrm{A} \beta$ oligomers, mitochondrial redox potential dropped precipitously. A marked decease in ATP level and drastic increases in caspase activation and lactate dehydrogenase (LDH) release were also observed prior to the occurrence of massive cell death (22). It also has been reported that synthetic $\mathrm{A} \beta$ inhibited activity of the human cytochrome $c$ oxidase and the inhibitory effect is dependent on the copper content $(23,24)$. Only in the presence of copper does $A \beta$ significantly inhibit the activity of human cytochrome $c$ oxidase in mitochondria. These results suggest that copper plays a significant role in the neurotoxicity of $\mathrm{A} \beta$.

The brain utilizes metal ions for many biochemical reactions, and cortical neurons release exchangeable copper and zinc ions during depolarization and neurotransmission $(25,26)$. Whether metal ions are involved in the pathogenesis of AD and what roles they play in the evolvement of oxidative stress and $\mathrm{AD}$ development are not known. Yet, the fact that senile plaques in the neocortical region of the brains of $\mathrm{AD}$ patients contain up to millimolar concentrations of $\mathrm{Zn}^{2+}, \mathrm{Cu}^{2+}$, and $\mathrm{Fe}^{3+}(27)$ suggests that metal ions probably play a pivotal role in the generation of reactive oxygen species (ROS). A recent study by Raman spectroscopy of senile plaques extracted from postmortem samples demonstrated that copper and zinc ions are bound via histidine imidazole rings (28). More importantly, it was found that extensive methionine oxidation in $A \beta$ has occurred in intact plaques (28). For metals to exert important influences on the AD pathogenesis, it is likely that a series of redox reactions facilitated by the metal-containing $A \beta$ species have occurred, leading to the production of ROS and/or the interruption of electron transfer (ET) chain in the respiratory processes. Along this line, $\mathrm{Cu}(\mathrm{II})$ coordination with $\mathrm{A} \beta$ has been extensively investigated (29-34). In support of the important role of copper-containing A $\beta$ species in ROS production, studies have shown that in vitro incubation of an $\mathrm{A} \beta / \mathrm{Cu}(\mathrm{II})$ mixture with electron donors under aerobic condition produced hydrogen peroxide (35-37). 
A number of techniques have been employed for examining the various aspects of the interactions between $\beta$-amyloid and copper ions (e.g. the structure of and binding sites in the complex) $(34,35,38,39)$. Although conflicting results have been reported on certain aspects (for example, the metal binding stoichiometry and affinity) $(29,34,38,39)$, it is generally accepted that metal ions are bound to the hydrophilic portion of $A \beta$ species (residues 1-16). Moreover, the involvement of histidine residues at positions 6, 13, and 14 has been ascertained by many studies $(30,34,38)$. Given the wide existence of ET processes in cells in general and neuronal cells in particular, the introduction of exogenous redox-active species may alter the ET reactions or pathways in mitochondria. The accurate determination of redox potentials of $A \beta$ and its metal complexes will certainly help unravel their roles in oxidative stress, metal homeostasis and detoxification, and $\mathrm{A} \beta$ aggregation/fibrillation. Surprisingly, other than a single experiment comparing the voltammetric behaviors of $A \beta(1-$ 42) and its copper complex (35), a systematic effort has not been made to measure accurately the redox potentials of metal complexes of the full-length and different segments of $A \beta$ and to relate them to redox reactions in cellular milieu. Moreover, there exist inconsistencies in the interpretations of the redox reactions of the A $\beta$-metal complexes (e.g., whether $\mathrm{Cu}$ (II) can be reduced by $\mathrm{A} \beta$ and, if the reduction does occur, which constituents in $\mathrm{A} \beta$ cause the reduction) $(27,35,37,40)$. Compounded by the complexity in $\mathrm{A} \beta$ structural elucidation and the possible involvement of $A \beta$ in many cellular processes, evidence regarding the effect of redox-active metal ions on ROS generation and the possible oxidations of the methionine residue near the $\mathrm{C}$ terminus (Met-35) and the tyrosine moiety in the hydrophilic domain (Tyr-10) remain either indirect or largely elusive.

Electrochemical methods can allow for the accurate and direct determination of potentials of redox-active biomolecules and provide insight about their ET reactions (41). By judiciously choosing the electrode materials and electrolyte system, one can achieve facile ET rates at the electrode/solution interface and reliably determine the redox potentials. In this study, we employed cyclic voltammetry (CV) and mass spectrometry (MS), to investigate the redox properties of several $A \beta$ variants and their copper complexes. We present strong evidence about the inability of $\mathrm{A} \beta$, in the absence of a cofactor (i.e., a reductant), to reduce $\mathrm{Cu}(\mathrm{II})$ and report on an experiment in which electrogenerated $\mathrm{A} \beta-\mathrm{Cu}(\mathrm{I})$ complex can indeed facilitate the catalytic reduction of dissolved oxygen to hydrogen peroxide. Based on the redox potential of $\mathrm{A} \beta-\mathrm{Cu}(\mathrm{II})$ and comparing it to those of selected cellular reductants, the implications of the $A \beta$ involvement in the production of ROS and the ET chain of mitochondria and their relations with $\mathrm{AD}$ pathogenesis are discussed.

\section{MATERIALS AND METHODS}

\section{Materials}

Lyophilized $A \beta(1-16), A \beta(1-28)$, and $A \beta(1-42)$

(DAEFRHDSGYEVHHQK ${ }^{16}$ LVFFAEDVGSNK ${ }^{28}$ GAIIGLMVGGVVIA ${ }^{42}$ ) samples were purchased from American Peptide Co. Inc. (Sunnyvale, CA). A $\beta(1-28)$ and A $\beta(1-42)$ samples, generously provided by Prof. C. Glabe (University of California at Irvine, CA), were also used in this study. No difference in terms of experimental results between the two sources of $A \beta$ samples was found. Other chemicals were of analytical grade (SigmaAldrich). All the aqueous solutions were prepared using Millipore water $(18 \mathrm{M} \Omega \mathrm{cm})$. Throughout the work, $1 \mathrm{mM} \mathrm{CuCl}_{2}$ dissolved in $1 \mathrm{mM} \mathrm{H}_{2} \mathrm{SO}_{4}$ was used as the $\mathrm{Cu}$ (II) stock solution. $A \beta(1-16)$ were prepared freshly by dissolving lyophilized powder samples in Millipore water or $5 \mathrm{mM} \mathrm{NaOH}$. No apparent difference was observed for electrochemistry and MS results between samples dissolved in water and those dissolved in $\mathrm{NaOH}$. To ensure no substantial aggregation occurs and to rid the solution of any aggregates, $\mathrm{A} \beta(1-28)$ and A $\beta(1-42$; ) samples were routinely prepared using a similar protocol developed by Teplow and coworkers (42) and Zorgowski and coworkers (43). Briefly, A $\beta$ stock solutions (0.5 
$\mathrm{mM}$ ) were prepared daily by dissolving the lyophilized $\mathrm{A} \beta$ in $5 \mathrm{mM} \mathrm{NaOH}$. This was followed by sonication for $1 \mathrm{~min}$. The as-prepared solutions were centrifuged at 13,000 rpm for $30 \mathrm{~min}$ and the supernatants were pipetted out for further dilutions. During the relatively short voltammetric and MS measurements, $A \beta(1-16)$ and $A \beta(1-28)$ were not found by atomic force microscopy to aggregate considerably, whereas small amounts of oligomers of $\mathrm{A} \beta(1-42)$ were observed. By decreasing the $\mathrm{A} \beta(1-28)$ concentration and adding $10 \%$ dimethylsulfoxide (DMSO) into the $A \beta(1-42)$ solution, aggregation in both cases was avoided or significantly retarded.

\section{Electrochemical measurements}

All the electrochemical experiments were performed on a $\mathrm{CHI} 832$ electrochemical workstation (CH Instruments, Austin, Texas) using a home-made plastic electrochemical cell. A glassy carbon disk electrode and a platinum wire were used as the working and counter electrodes, respectively. The reference electrode was $\mathrm{Ag} / \mathrm{AgCl}$ and all the potential values are reported with respect to this electrode unless otherwise stated. Prior to each experiment, the glassy carbon electrode was polished with diamond pastes of 15 and $3 \mu \mathrm{m}$ and alumina pastes of 1 and $0.3 \mu \mathrm{m}$ in diameter (Buehler, Lake Bluff, IL). The electrolyte solution was a $10 \mathrm{mM}$ phosphate buffer $(\mathrm{pH}, 7.4)$ containing $0.1 \mathrm{M} \mathrm{Na}_{2} \mathrm{SO}_{4}$. Although it has been noted that different buffer solutions may affect $\mathrm{A} \beta / \mathrm{Cu}$ (II) binding and the subsequent $\mathrm{H}_{2} \mathrm{O}_{2}$ generation, we did not test other buffers because $\mathrm{H}_{2} \mathrm{O}_{2}$ had been detected in phosphate buffer containing $\mathrm{A} \beta$ and $\mathrm{Cu}(\mathrm{II})$.(37) Thus, the voltammetric studies in such an electrolyte solution are more relevant to the elucidation of the redox reactions of $\mathrm{A} \beta-\mathrm{Cu}(\mathrm{II})$ and $\mathrm{H}_{2} \mathrm{O}_{2}$ generation. For $A \beta(1-16)$ and $A \beta(1-28)$, aliquots of $A \beta$ from stock solutions were diluted with the phosphate buffer to desired concentrations. For voltammetric studies in the presence of $\mathrm{Cu}(\mathrm{II})$, these $\mathrm{A} \beta$ solutions were spiked with the $\mathrm{Cu}$ (II) stock solution to different $\mathrm{A} \beta / \mathrm{Cu}(\mathrm{II})$ molar ratios. For voltammetric studies of $\mathrm{A} \beta(1-42)$, the same procedures were employed except that the $10 \mathrm{mM}$ phosphate/0.1 $\mathrm{M} \mathrm{Na}_{2} \mathrm{SO}_{4}$ (pH 7.4) solution containing $10 \%$ dimethylsulfoxide was chosen to retard the rapid aggregation of $\mathrm{A} \beta(1-42)$.

\section{Detection of hydrogen peroxide}

Based on the voltammetric data ( $c f$. Results Section), the electrode potential was held at 0.07 $\mathrm{V}$ to reduce the $\mathrm{A} \beta / \mathrm{Cu}$ (II) complex. Possible $\mathrm{H}_{2} \mathrm{O}_{2}$ generation was monitored using the Fluoro $\mathrm{H}_{2} \mathrm{O}_{2}$ detection kit (Cell Technology Inc., Mountain View, CA). In the presence of $\mathrm{H}_{2} \mathrm{O}_{2}$, 10-acetyl-3,7-dihydroxyphenoxazine (ADHP) is oxidized to a fluorescent product, resorufin. This reaction is rapidly catalyzed by peroxidase in a homogeneous solution. Briefly, $50 \mu \mathrm{L}$ of the sample solution was added to $50 \mu \mathrm{L}$ aliquot of the reaction cocktail, which contained $100 \mu \mathrm{L}$ of $10 \mathrm{mM}$ ADHP, $200 \mu \mathrm{L}$ of $10 \mathrm{U} / \mathrm{mL}$ horseradish peroxidase, and $4.7 \mathrm{~mL}$ of reaction buffer. The mixture was then incubated at room temperature in dark for $10 \mathrm{~min}$. Subsequently the fluorescence intensity of resorufin was measured at an excitation wavelength of $550 \mathrm{~nm}$ with a Cary Eclipse Spectrofluorometer (Varian, Inc, Palo Alto, CA). By comparing the fluorescence intensity of resorufin of the sample solution to that of the control, $\mathrm{H}_{2} \mathrm{O}_{2}$ can be detected.

\section{Electrospray ionization-Fourier transform ion cyclotron mass spectrometry (ESI-FTICR- MS)}

The ESI-FTICR-MS experiments were conducted on an IonSpec FT-ICR mass spectrometer equipped with a 4.7-Tesla superconducting magnet (IonSpec Inc., Lake Forest, CA) and an LTQ linear-ion trap mass spectrometer (Thermo Fisher Scientific, San Jose, CA) operated in the high-resolution, "ultra zoom scan" mode. For the MS measurements, $A \beta$ was first dissolved in a water/methanol solution (50/50 volume ratio) to yield a 50- $\mu \mathrm{M} \mathrm{A} \beta$ stock solution. Aliquots were then diluted with the water/methanol solution to a final concentration of $5 \mu \mathrm{M}$. The $\mathrm{A} \beta$ solution and $\mathrm{A} \beta$ solution spiked with $\mathrm{CuCl}_{2}$ at different 
molar ratios were introduced to and analyzed by MS. The typical mass resolving power for the FTICR-MS is approximately 200,000 .

\section{RESULTS}

\section{Copper binds $A \beta$ at 1:1 molar ratio and the oxidation state of copper is +2}

The coordination chemistry between $\mathrm{Cu}(\mathrm{II})$ and $\mathrm{A} \beta$ has been investigated by various techniques, such as circular dichroism (CD) spectroscopy $(34,35)$, electron spin resonance (ESR) $(34,35,38)$ and nuclear magnetic resonance (NMR) $(34,39)$. While all the studies indicate that $\mathrm{Cu}$ (II) can be incorporated mainly in the hydrophilic domain (residues 1 through 16), contradictory results have been reported regarding the coordination stoichiometry, the ligands involved, and the oxidation state of copper. A few papers suggested that $\mathrm{A} \beta-\mathrm{Cu}(\mathrm{II})$ binding ratio is $1: 2(29,34)$, whereas other papers showed that the ratio should be 1:1 $(38,39)$. MS can provide evidence for the number of copper ions bound per A $\beta$ molecule. ESI-MS is particularly advantageous in that the soft ionization by ESI generates multiply charged species of proteins or peptides while keeping the molecular ions intact. Formation of multiply charged species also decreases the mass-to-charge ratios, shifting molecular ions of large biomolecules to the mass range readily accessible by most mass analyzers (44). Furthermore, when the MS employed has a high resolving power, the analysis of isotopic peaks affords an opportunity to deduce the oxidation state of the ligated metal ion. To our knowledge, the use of ESI coupled with high-resolution MS to study A $\beta$ metal ion binding has not been reported.

The predominate peaks in the ESI-FTICR mass spectra indicate that $A \beta$ and its copper complex are of the $3+, 4+$, and 5+ charge states, with the 4+ charge state being the most abundant. Figure 1 shows the $\mathrm{m} / \mathrm{z}$ range covering the peaks corresponding to the $4+$ charge states of free $\mathrm{A} \beta(1-28)$ and its copper complex. Clustered around $m / z 816$ and $m / z 832$ are the various isotopic peaks of the quadruply charged $A \beta(1-28)$ and $A \beta(1-28)$-copper ion complex, respectively. An ESI-FTICR mass spectrum of $\mathrm{A} \beta(1-28)$ in the absence of $\mathrm{Cu}^{2+}$ exhibited peaks at around $m / z 816$ (See Figure $S 1$ in the Supporting Information). The difference in the mass between the monoisotopic peaks of free $\mathrm{A} \beta(1-28)$ and $\mathrm{A} \beta(1-28)-\mathrm{Cu}$ complex is $4 \times(831.387-816.142)=60.980 \mathrm{Da}$. Since the monoisotopic $\mathrm{A} \beta(1-28)-\mathrm{Cu}(\mathrm{II})$ complex has two less protons, the actual mass difference is $60.980+2=62.980$, which is close to the nominal mass of a copper ion. Therefore, the ESI-MS result supports that the binding stoichiometry between $\mathrm{A} \beta(1-28)$ and $\mathrm{Cu}$ is $1: 1$. Further increasing the molar ratio between $\mathrm{Cu}(\mathrm{II})$ and $\mathrm{A} \beta(1-28)$ (up to 10) in the solution only changed the relative intensities of the free $A \beta(1-28)$ and $A \beta(1-28)-C u(I I)$ peaks, but did not create other peaks of different binding stoichiometries (e.g., 1:2 or 2:1).

The oxidation number of the copper ion in the complex can be determined from the measured $\mathrm{m} / \mathrm{z}$ values of the $4+$ ion of the complex. In this respect, if $\mathrm{Cu}(\mathrm{I})$ is involved in the formation of the complex, the complex will need to be associated with three protons to yield a 4+ ion; on the other hand, if $\mathrm{Cu}$ (II) is present in the complex, it would only require two protons to give a quadruply charged ion. The oxidation number of copper ion present in the complex can, therefore, be determined by comparing the experimentally measured $\mathrm{m} / \mathrm{z}$ values of the isotope clusters for the quadruply charged complex with the calculated $\mathrm{m} / \mathrm{z}$ values for the complexes that are associated with either $\mathrm{Cu}(\mathrm{I})$ or $\mathrm{Cu}(\mathrm{II})$ (see Table 1). Clearly, the deviations between the measured and calculated $m / z$ values for the $\mathrm{Cu}$ (II)complex are 15-23 ppm, which are markedly smaller than the 280-290 ppm deviations found for the differences between the measured and calculated $\mathrm{m} / \mathrm{z}$ values for the $\mathrm{Cu}(\mathrm{I})$ complex. These results, therefore, strongly support that the charge state of copper ion in the A $\beta(1-28)$-copper complex is $2+$. Similar analysis of the isotope cluster peaks for the $3+$ ion leads to the same conclusion (Table 1). 
It has been proposed that $\mathrm{Cu}(\mathrm{II})$, in the presence of dissolved oxygen, could alter the redox state of $A \beta(1-42)$, possibly by oxidizing Met-35 into its sulfoxide or sulfone analogs (30, $35,36)$. Thus, since $A \beta(1-28)$ does not comprise the methionine residue, it is conceivable that $\mathrm{Cu}(\mathrm{II})$ remains unchanged upon binding to $\mathrm{A} \beta(1-28)$. However, there has been a lack of direct spectroscopic evidence for chemical modifications of methionine even in $A \beta(1-42)$ (except for samples produced under extreme conditions such as laser photolysis (45) or from autopsy (28)). It has been further contended that Met-35 oxidation could change the $\mathrm{Cu}(\mathrm{II})$ center to $\mathrm{Cu}(\mathrm{I})$, which remains coordinated by $\mathrm{A} \beta(1-42)(28,35)$. If the methionine residue were chemically modified or the copper ion oxidation state were changed, the mass spectra of $\mathrm{A} \beta(1-42)$ treated with $\mathrm{Cu}(\mathrm{II})$ would contain peaks showing the addition of oxygen or different $\mathrm{m} / \mathrm{z}$ values for the isotope clusters (vide supra).

To verify whether the ligated $\mathrm{Cu}$ (II) could oxidize methionine, we collected mass spectra by spraying a solution containing $\mathrm{A} \beta(1-42)$ and $\mathrm{Cu}(\mathrm{II})$. Figure 2 is a representative mass spectrum in the mass range encompassing the $4+$ charge states of $A \beta(1-42)$ and $A \beta(1-42)$ copper ion complex. In Figure 2, peaks corresponding to both free $A \beta(1-42)$ and $A \beta(1-42)$ $\mathrm{Cu}(\mathrm{II})$ complex were observed, but any peaks associated with oxidized $\mathrm{A} \beta(1-42)$ were absent. This observation strongly suggests that, under the present experimental conditions, $\mathrm{A} \beta(1-42)$ itself cannot be oxidized by $\mathrm{Cu}(\mathrm{II})$. This observation is further supported by our voltammetric data (vide infra). A detailed analysis of the positions of the peaks corresponding to the 4+ and 5+ charge states again indicates that $\mathrm{Cu}$ (II) was not reduced (Table 2), consistent with the fact that the methionine residue was not chemically modified. Our results are also in good agreement with the report from the Zagorski group who conducted NMR measurements of $\mathrm{A} \beta(1-40)$ in the presence of $\mathrm{Cu}(\mathrm{II})$ and demonstrated that Met-35 oxidation and $\mathrm{Cu}(\mathrm{II})$ reduction did not occur (39). We conducted two additional experiments to show that $\mathrm{A} \beta(1-42)-\mathrm{Cu}(\mathrm{II})$ complex is indeed formed by mixing $\mathrm{Cu}(\mathrm{II})$ with $\mathrm{A} \beta(1-42)$. First, an FT-ICR mass spectrum collected from spraying a solution containing $\mathrm{A} \beta(1-42)$ did not exhibit peaks around $m / z 1145$ (Figure S2), indicating that $\mathrm{A} \beta(1-42)$ $\mathrm{Cu}(\mathrm{II})$ does not exist in the absence of $\mathrm{Cu}(\mathrm{II})$. The second experiment involves the confirmation of the $\mathrm{A} \beta(1-42)-\mathrm{Cu}(\mathrm{II})$ complex peak with ESI-MS measurement on a linearion trap mass spectrometer. As can be seen in Figure S3 and Table S1 in the Supporting Information section, the peaks around 1145 are even more pronounced. Due to the greater mass resolving power of FTICR-MS and to be consistent in comparing the spectra among various species, we focused mainly on the FTICR-MS results.

\section{Redox potentials of $\mathrm{A} \beta-\mathrm{Cu}(\mathrm{II})$ complexes}

Since the proposed copper binding sites reside in the 16-amino acid $\mathrm{N}$-terminal segment of $\mathrm{A} \beta(1-42)$, we first examined the redox behavior of $\mathrm{A} \beta(1-16)$ with or without $\mathrm{Cu}(\mathrm{II})$. Figure 3 is an overlay of voltammograms of $\mathrm{A} \beta(1-16)$ in a $\mathrm{Cu}(\mathrm{II})$-free solution (thick solid curve), free $\mathrm{Cu}(\mathrm{II})$ (dashed curve), and $\mathrm{A} \beta(1-16)$ in the presence of an equimolar amount of $\mathrm{Cu}(\mathrm{II})$ (thin solid curve). To examine the effect of oxygen on the redox process involving $\mathrm{A} \beta(1-$ 42 ), we also bubbled $\mathrm{O}_{2}$ into the mixture of $\mathrm{Cu}(\mathrm{II})$ and $\mathrm{A} \beta(1-16)$ and then recorded the voltammogram (dash-dot-dash curve). Notice that the voltammogram of $A \beta(1-16)$ (thick solid curve) is rather different than that of $\mathrm{Cu}$ (II) (dashed curve), which produced an irreversible reduction peak starting from around $0.0 \mathrm{~V}$. This peak can be attributed to the catalytic reduction of oxygen by electrogenerated $\mathrm{Cu}_{2} \mathrm{O}$ or $\mathrm{CuOH}$ layer (46). Due to the presence of trace amount of oxygen in solution, the follow-up catalytic oxidation of $\mathrm{Cu}_{2} \mathrm{O}$ or $\mathrm{CuOH}$ prevents $\mathrm{Cu}_{2} \mathrm{O}$ or $\mathrm{CuOH}$ from being further reduced to $\mathrm{Cu}(0)$. Therefore no copper stripping peak was observed. By thoroughly purging the solution with $\mathrm{N}_{2}$, a copper stripping peak was observed in the CV (Figure S4). The comparison of the voltammogram of $A \beta(1-$ 16)- $\mathrm{Cu}$ (II) (thick solid curve in Figure 3 ) to the $\mathrm{Cu}$ (II) reduction voltammogram shows that the reduction current of $\mathrm{A} \beta(1-16)-\mathrm{Cu}(\mathrm{II})$ complex is smaller, even though the concentration 
of the former is twice as high as that of the latter. This suggests that $\mathrm{Cu}(\mathrm{II})$ is complexed, since the $A \beta(1-16)-\mathrm{Cu}(\mathrm{II})$ is expected to have a smaller diffusion coefficient. For the mixture of $\mathrm{A} \beta(1-16)$ and $\mathrm{Cu}(\mathrm{II})$, a pair of quasi-reversible waves (thin solid curve) was observed with an oxidation peak at $0.17 \mathrm{~V}$ and a reduction peak at ca. $0.0 \mathrm{~V}$. The peak currents decrease inversely with the $\mathrm{A} \beta(1-16): \mathrm{Cu}(\mathrm{II})$ molar ratio (Table S2). Apparently, catalytic reduction of $\mathrm{O}_{2}$ by electrogenerated $\mathrm{Cu}_{2} \mathrm{O}$ or $\mathrm{CuOH}$ occurs at a different potential $(<-0.1 \mathrm{~V})$ than the $\mathrm{A} \beta(1-16)-\mathrm{Cu}(\mathrm{II})$ complex. We thus assign this pair of waves to the redox reactions between the $\mathrm{A} \beta(1-16)-\mathrm{Cu}(\mathrm{II})$ and $\mathrm{A} \beta(1-16)-\mathrm{Cu}(\mathrm{I})$ complexes and report the reduction potential of $\mathrm{A} \beta(1-16)-\mathrm{Cu}(\mathrm{II})$ to be $0.085 \mathrm{~V}$ vs. $\mathrm{Ag} / \mathrm{AgCl}$. We noticed that this potential value is similar to that of histidine-rich peptide- $\mathrm{Cu}$ (II) complexes (46-48). The fact that the reduction peak is higher than the oxidation peak suggests that a catalytic follow-up reduction (49) takes place after $\mathrm{A} \beta(1-16)-\mathrm{Cu}(\mathrm{II})$ is reduced. Another noteworthy point is that the oxidation peak became more pronounced as the potential scan rate is increased (data not shown). Furthermore, in the dash-dot-dash curve of Figure 3 the reduction peak was found to increase at the expense of the oxidation peak, suggesting the catalytic nature of the reaction and the involvement of $\mathrm{O}_{2}$.

The A $\beta$ (1-16) voltammogram exhibited a small and broad oxidation peak at the anodic side of Figure 3 (ca. $0.78 \mathrm{~V}$ ). This oxidation peak is irreversible and disappears after the first cycle, and was observable even when $\mathrm{Cu}$ (II) was present (Note: the thin solid and dash-dotdash curves in Figure 3 were acquired during the second cycle). Thus the peak must originate from the oxidation of a segment of the peptide and is irrelevant to the $\mathrm{Cu}$ (II) redox reaction. The peak potential is the same as that of $A \beta(1-42)$ reported by and attributed to the Tyr-10 residue by Vestergaard et. al. (50). That the voltammogram of tyrosine solution alone (inset in Fig. 3) also showed an oxidation peak at a similar potential confirms our assignment. A tyrosine residue could undergo a two-electron, two-proton oxidation reaction (51), as depicted below:

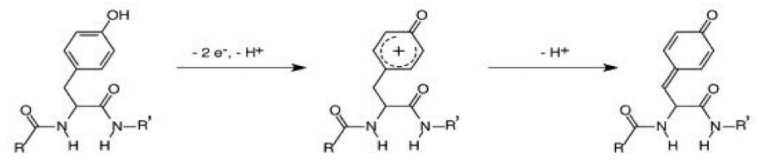

In view that the hydrophobic segment in the $\mathrm{A} \beta-\mathrm{Cu}(\mathrm{II})$ complex may affect the $\mathrm{A} \beta$ redox behavior, we conducted voltammetric experiments on $A \beta(1-28)$ in the absence and presence of $\mathrm{Cu}(\mathrm{II})$. Superimposed in Figure 4 are the voltammograms of $A \beta(1-28)$ alone (dashed curve) and $\mathrm{A} \beta(1-28)$ in the presence of an equimolar amount of $\mathrm{Cu}(\mathrm{II})$ (solid curve). The remarkable resemblance in the peak shapes between $\mathrm{A} \beta(1-16)-\mathrm{Cu}(\mathrm{II})$ and $\mathrm{A} \beta(1-28)-\mathrm{Cu}(\mathrm{II})$ indicates that the more hydrophobic segment in $\mathrm{A} \beta(1-28)$ does not affect the redox potentials of both the $\mathrm{Cu}(\mathrm{II})$ center and the Tyr-10 residue. In addition, $\mathrm{A} \beta(1-28)$ (dashed curve) has similar redox behavior as $A \beta(1-16)$. The main difference is that $A \beta(1-28)$ is more prone to aggregation and causes a more significant adsorption onto the electrode surface. To alleviate this effect, we decreased the concentration of $A \beta(1-28)$ for the acquisition of the voltammograms in Figure 4. Again, analogous to $A \beta(1-16), A \beta(1-28)$ displayed an oxidation peak at ca. $0.78 \mathrm{~V}$, which can be ascribed to the Tyr-10 oxidation.

To clearly illustrate the effect of $\mathrm{O}_{2}$ on the magnitude of the $\mathrm{A} \beta-\mathrm{Cu}(\mathrm{II})$ reduction peak, we subtracted the voltammograms of $\mathrm{A} \beta(1-28) / \mathrm{Cu}$ (II) in a $\mathrm{N}_{2}$-purged solution from those of the same solution saturated with air (Figure 5). The plateaus at slow scan rates (e.g., $0.02 \mathrm{~V} /$ s) developed into peaks at higher scan rates. These features are again typical of an electrocatalytic reduction(49) and are also consistent with our findings related to $\mathrm{A} \beta(1-16)$ (vide supra). For oxygen to be catalytically reduced, oxygen molecules need to diffuse to and become associated with the newly electrogenerated $\mathrm{A} \beta(1-28)-\mathrm{Cu}(\mathrm{I})$ center. We should note that, without background subtraction, the dependence of the steady-state current on $\mathrm{O}_{2}$ 
purged into the solution is not as obvious. This suggests that the $\mathrm{O}_{2}$ reduction is a diffusioncontrolled process. Thus, $\mathrm{O}_{2}$, which is hydrophobic, appears to have interacted more strongly with the hydrophobic segment inherent in $\mathrm{A} \beta(1-28)$ and consequently its movement towards the $\mathrm{A} \beta-\mathrm{Cu}(\mathrm{II})$ center is retarded (52).

We then extended the same approach to the study of $A \beta(1-42)$ and its complex with $\mathrm{Cu}(\mathrm{II})$. Since $A \beta(1-42)$ has the strongest propensity to form aggregates, we added a small amount of dimethylsulfoxide (see Experimental) into the solution to impede the $\mathrm{A} \beta$ aggregation and to improve the reproducibility of the experiment. Several points can be extracted from the voltammograms in Figure 6. First, in the cathodic range (solid curve), the redox behavior of the $\mathrm{A} \beta(1-42)-\mathrm{Cu}(\mathrm{II})$ is highly comparable to those of the $\mathrm{A} \beta(1-16)$ and $\mathrm{A} \beta(1-28)$ counterparts. Accordingly, we assigned the peak at $\sim 0.02 \mathrm{~V}$ to the reduction of $\mathrm{A} \beta(1-42)$ $\mathrm{Cu}$ (II) to $\mathrm{A} \beta(1-42)-\mathrm{Cu}(\mathrm{I})$ and conclude that the redox potential of the $\mathrm{Cu}(\mathrm{II})$ center remains largely unaffected by the length of the hydrophobic segment of $A \beta$. Although the reduction current is much greater than the oxidation current during scan reversal, purging the solution with oxygen and nitrogen led to little change in the peak heights. This is in contrast to the cases of the shorter $\mathrm{A} \beta$ variants ( $c f$. Figures 3 and 5). The insensitivity of reduction or oxidation current of the $\mathrm{A} \beta(1-42)-\mathrm{Cu}(\mathrm{II})$ complex to the oxygen concentration could be caused by the slow coordination of oxygen molecules with the $\mathrm{A} \beta(1-42)-\mathrm{Cu}(\mathrm{I})$ center due to the greater steric hindrance imposed by the longer length and the greater hydrophobicity of the $\mathrm{A} \beta(1-42)$ strand.

In the anodic range of the $\mathrm{CV}$, a pair of small peaks, with the reduction peak potential at ca. $0.48 \mathrm{~V}$ and the oxidation peak potential at ca. $0.6 \mathrm{~V}$, were observed. Again, these peaks are independent of $\mathrm{Cu}(\mathrm{II})$, since the peaks in solid and dashed curves in Figure 6 are almost congruent in this range. These peaks were assigned to the redox reaction of the $\mathrm{Cu}$ (II) center to its $\mathrm{Cu}(\mathrm{I})$ counterpart by Huang et al. (35). However, given its close proximity to the oxidation peak of Tyr-10 ( $c f$. inset of Figure 3 and the reported value (50)) and its independence of $\mathrm{Cu}$ (II) in the solution, we feel that the assignment to the Tyr-10 redox reaction is more plausible. The greater reversibility of tyrosine oxidation in $A \beta(1-42)$ with respect to those of $A \beta(1-16)$ and $A \beta(1-28)$ may be partially contributed by the adsorbate nature of $A \beta(1-42)$. Moreover, it is well known that adsorption of redox species onto the electrode tends to yield redox peaks whose positions are different than those originated from the soluble species (49).

\section{$\mathrm{A} \beta-\mathrm{Cu}(\mathrm{I})$ complex catalyzes the reduction of oxygen to hydrogen peroxide}

As mentioned above, the reduced form of the $\mathrm{A} \beta-\mathrm{Cu}(\mathrm{II})$ complex can catalyze oxygen reduction, producing $\mathrm{H}_{2} \mathrm{O}_{2}$ as one of the possible products $(30,35,37)$. To directly link the redox state of the $\mathrm{Cu}$-containing $\mathrm{A} \beta$ complex to the $\mathrm{H}_{2} \mathrm{O}_{2}$ production, we carried out spectrofluorometric detection of $\mathrm{H}_{2} \mathrm{O}_{2}$ from $\mathrm{A} \beta(1-16) / \mathrm{Cu}(\mathrm{II}), \mathrm{A} \beta(1-28) / \mathrm{Cu}(\mathrm{II})$, and $\mathrm{A} \beta(1-$ $42) / \mathrm{Cu}(\mathrm{II})$ solutions that had been subject to controlled potential electrolyses.

After electrolyses of these solutions at $0.07 \mathrm{~V}$ for a period of time, the solutions were analyzed by a hydrogen peroxide detection kit. We chose $0.07 \mathrm{~V}$ because it is at the plateaus of the electrocatalytic reduction peaks of all the $A \beta$ variants (thin solid curve in Figure 3 and solid curves in Figures 4 and 6). At this potential the complication of possible catalytic reduction of oxygen by unbound copper ion can also be excluded (i.e., the potential is more positive than the onset potential of free $\mathrm{Cu}(\mathrm{II})$ reduction; $c f$. the dashed curve in Figure 3 ). As shown in Fig. 7, for all three $A \beta$ variants, the fluorescence peak heights increase with the electrolysis time. Moreover, the resorufin fluorescence peaks are significantly greater than those in the buffer and $\mathrm{Cu}$ (II) solutions. Notice that the fluorescence intensity from the electrolyzed $\mathrm{Cu}$ (II) solution was not different than that from the buffer solution, again suggesting that the catalytic reaction involving $\mathrm{Cu}$ (II) and $\mathrm{O}_{2}$ occurs at a different potential. 
$\mathrm{A} \beta-\mathrm{Cu}(\mathrm{II})$ complex solutions without being electrolyzed also exhibited similar responses to those of the buffer solution. All these observations indicate that it is the reduced $\mathrm{A} \beta-\mathrm{Cu}(\mathrm{II})$ complex that is responsible for the $\mathrm{H}_{2} \mathrm{O}_{2}$ production.

A point particularly worth noting is that the fluorescence intensity increases inversely with the length of the $A \beta$ variants. This explains why the catalytic reduction current becomes less sensitive to the concentration of dissolved oxygen as the $A \beta$ strand becomes longer. Such a consistency reinforces our earlier contention that the movement of oxygen to the electrogenerated $\mathrm{Cu}(\mathrm{I})$ center is dependent on both the length and hydrophobicity of the $\mathrm{A} \beta$ strand.

\section{DISCUSSION}

As mentioned in the Introduction, it is generally believed that the $\mathrm{Cu}$ (II) binding domain in $\mathrm{A} \beta$ is within the segment comprising residues 1-14 (30, 34, 38, 53), with His-6 , His-13, and His-14 having the strongest metal binding affinities. Our ESI-FTICR-MS study has demonstrated that the binding ratio between $\mathrm{Cu}(\mathrm{II})$ and $\mathrm{A} \beta(1-28)$ or $\mathrm{A} \beta(1-42)$ is $1: 1$, which is consistent with results by Karr et al. (38) and Garzon-Rodriguez et. al. (54). We did not find other binding ratios as reported by others $(29,34)$. The ESI-FTICR-MS results are also in good agreement with our voltammetric data, which showed that the reduction current of $\mathrm{A} \beta(1-16)-\mathrm{Cu}(\mathrm{II})$ complex leveled off once the molar ratio between $\mathrm{Cu}(\mathrm{II})$ and $\mathrm{A} \beta(1-16)$ had exceeded 1:1.

The reduction potentials of $\mathrm{A} \beta-\mathrm{Cu}(\mathrm{II})$ deduced from Figures 3,4 , and 6 allowed us to gain insight about the factors or redox species that could be involved in the reduction of the $A \beta$ $\mathrm{Cu}$ (II) complex in the cellular milieu. Thus, for example, to reduce $\mathrm{A} \beta(1-42)-\mathrm{Cu}(\mathrm{II})$, a species must have a reduction potential that is more negative (cathodic) than $0.08 \mathrm{~V} v s . \mathrm{Ag} /$ $\mathrm{AgCl}$ or $0.28 \mathrm{~V} v s$. normal hydrogen electrode, NHE ( $c f$. Figure 6 and Table 3). Since the Tyr-10 redox peak appeared at $\sim 0.78 \mathrm{~V}$, we conclude that Tyr- 10 cannot reduce $\mathrm{A} \beta(1-42)$ $\mathrm{Cu}$ (II) in vitro. Several reports have suggested that Tyr-10 participates in the metal ion coordination. A Raman analysis of samples from deceased AD patients' brains indicated that the tyrosine residue in $\mathrm{A} \beta(1-42)$ was oxidized (28). Thus, it is clear that the $\mathrm{A} \beta-\mathrm{Cu}(\mathrm{II})$ complex is not the sole species responsible for the Tyr-10 oxidation, and other cellular species or processes must be involved. Another amino acid residue that is susceptible to oxidation and has been implicated in the reduction of $\mathrm{A} \beta-\mathrm{Cu}(\mathrm{II})$ and generation of ROS such as $\mathrm{H}_{2} \mathrm{O}_{2}$ is Met-35 $(30,45,55)$. However, from the ESI-FTICR-MS data, we did not find ions corresponding to oxidized or chemically modified (e.g., oxygenated adducts) $\mathrm{A} \beta(1-42)$ and/or $\mathrm{A} \beta(1-42)-\mathrm{Cu}(\mathrm{II})$. Previously the peak potential for the Met-35 oxidation to its radical cation has been reported to exceed $1.3 \mathrm{~V} v s . \mathrm{Ag} / \mathrm{AgCl}$ in aqueous solution (56). Such a value is almost $1.2 \mathrm{~V}$ more positive than the $\mathrm{A} \beta-\mathrm{Cu}$ (II) reduction potential, suggesting that Met-35 would not be a viable reductant under the in-vitro condition. Moreover, in the natively unstructured $A \beta(1-40)$ or $A \beta(1-42)$ monomer, there is a wide separation between the metal center (close to the $\mathrm{N}$ terminus) and Met-35 (in the vicinity of the $\mathrm{C}$ terminus), which is unfavorable for facile ET. Therefore, based on the MS and voltammetric data, we also ruled out the possibility that Met-35 had undergone oxidation reactions with $\mathrm{Cu}(\mathrm{II})$ in solution and/or $\mathrm{Cu}(\mathrm{II})$ in the complex without involving other cellular species. This conclusion is in agreement with what was found by Hou and Zagorski (39).

In solution, $\mathrm{A} \beta$ binds $\mathrm{Cu}(\mathrm{II})$, and under an externally applied potential, the resultant $\mathrm{A} \beta$ $\mathrm{Cu}(\mathrm{II})$ complex can be reduced to $\mathrm{A} \beta-\mathrm{Cu}(\mathrm{I})$, once the cathodic scan has passed $\sim 0.080 \mathrm{~V}$ :

$$
\mathrm{A} \beta-\mathrm{Cu}(\mathrm{II})+\mathrm{e}^{-}=\mathrm{A} \beta-\mathrm{Cu}(\mathrm{I})
$$


Notice that the reduction potential for $\mathrm{A} \beta$-Cu(II) complex is quite different than that reported by Huang et al.(35). As the redox potentials of copper complexed by histidinecontaining peptides are in the range between -0.1 and $0.1 \mathrm{~V}(46-48,57,58)$, we believe that the redox potential around $0.1 \mathrm{~V}$ is more reasonable.

In the presence of dissolved oxygen, the electroreduced $\mathrm{A} \beta-\mathrm{Cu}(\mathrm{I})$ center could react with $\mathrm{O}_{2}$ in solution, producing $\mathrm{H}_{2} \mathrm{O}_{2}$ :

$$
2 \mathrm{~A} \beta-\mathrm{Cu}(\mathrm{I})+\mathrm{O}_{2}+2 \mathrm{H}^{+}=2 \mathrm{~A} \beta-\mathrm{Cu}(\mathrm{II})+\mathrm{H}_{2} \mathrm{O}_{2}
$$

The above reaction is responsible for the $\mathrm{O}_{2}$-dependent reduction peaks exhibited in Figures $3-6$. As the potential for the $\mathrm{A} \beta-\mathrm{Cu}(\mathrm{II}) / \mathrm{A} \beta-\mathrm{Cu}(\mathrm{I})\left(0.28 \mathrm{~V} v s\right.$. NHE) is lower than that for $\mathrm{O}_{2} /$ $\mathrm{H}_{2} \mathrm{O}_{2}(0.295 \mathrm{~V} v s$. NHE, Table 3), reaction (2) is thermodynamically allowed. A much higher potential for $\mathrm{A} \beta-\mathrm{Cu}(\mathrm{II}) / \mathrm{A} \beta-\mathrm{Cu}(\mathrm{I})$, as that reported in $\operatorname{Ref}(35)(0.55 \mathrm{~V} v s . \mathrm{Ag} / \mathrm{AgCl})$, however, would cause Reaction (2) to proceed in the reverse direction (i.e., $\mathrm{H}_{2} \mathrm{O}_{2}$ oxidation). Thus, our measured potential value explains the catalytic reduction of $\mathrm{O}_{2}$ to $\mathrm{H}_{2} \mathrm{O}_{2}$ better. We should point out that the present study cannot rule out the possibility that some $\mathrm{O}_{2}$ might be reduced to $\mathrm{H}_{2} \mathrm{O}$ in a similar fashion to that catalyzed by $\mathrm{Cu}(\mathrm{II})$-containing enzymes such as laccase.(59) However, the $\mathrm{A} \beta-\mathrm{Cu}(\mathrm{II})$ complexes are not considered to be "enzymes", and the direct four-electron reduction of $\mathrm{O}_{2}$ to $\mathrm{H}_{2} \mathrm{O}$ typically involves multiple copper centers.(59) Furthermore, based on the $\mathrm{H}_{2} \mathrm{O}_{2}$ detected and other published data (37), the reactions outlined above should constitute the major mechanism. To further confirm the proposed mechanism, we simulated the kinetics of ET reaction and the follow-up catalytic oxygen reduction. The simulated voltammogram, overlaid with the experimentally measured one, is provided in the Supporting Information, together with the parameters used for the simulation. The heterogeneous ET rate constant for $\mathrm{A} \beta(1-16)-\mathrm{Cu}(\mathrm{II})$ at the electrode was estimated to be about $5 \times 10^{-4} \mathrm{~s}^{-1}$ and the follow-up catalytic reaction rate constant was deduced to be about $1000 \mathrm{M}^{-1} \mathrm{~s}^{-1}$. The reasonable agreement between the experimental and simulated voltmmograms suggests that the proposed mechanism is quite likely. Moreover, the rather high reaction rate constant deduced for equation 2 indicates that there is a strong tendency for the reduced $A \beta-C u(I I)$ complex to catalytically reduce $\mathrm{O}_{2}$ to $\mathrm{H}_{2} \mathrm{O}_{2}$. The rapid depletion of ascorbic acid (Figure S6), initiated by the $\mathrm{A} \beta-\mathrm{Cu}$ (II) complex, indicates the fast turnover rate (vide infra).

Based on our spectrofluoremetric measurements (Figure 7), it is clear that a prerequisite for $\mathrm{H}_{2} \mathrm{O}_{2}$ generation is the conversion of $\mathrm{A} \beta-\mathrm{Cu}(\mathrm{II})$ to $\mathrm{A} \beta-\mathrm{Cu}(\mathrm{I})$. The difference in the dependence of the catalytic peak currents on the $\mathrm{O}_{2}$ content in solution among the three $\mathrm{A} \beta$ $\mathrm{Cu}$ (II) complexes implies that in $\mathrm{AD}$ patients, the amount of $\mathrm{H}_{2} \mathrm{O}_{2}$ produced in Reaction (2) is likely to be dependent on the $A \beta$ sequence and length. It is generally known that $A \beta(1-$ 42 ) has a much stronger tendency to aggregate than $A \beta(1-40)$, and the $A \beta(1-42)$ content in senile plaques of $\mathrm{AD}$ patients is disproportionately high (60). Given the relatively high affinity of $A \beta$ species towards metal ions, it has been shown that $A \beta$ and its aggregates, upon complexation with redox-active metal ions such as $\mathrm{Cu}(\mathrm{II})$ and $\mathrm{Fe}(\mathrm{III})$, can generate $\mathrm{H}_{2} \mathrm{O}_{2}(35,37)$. The level of $\mathrm{H}_{2} \mathrm{O}_{2}$ can be sufficiently high to cause cell death (37). Based on the aforementioned dependence of $\mathrm{H}_{2} \mathrm{O}_{2}$ amount on the strand length of $\mathrm{A} \beta$ species, we postulate that there might exist an alternative process responsible for the slow onset of $\mathrm{AD}$ symptom. If Reactions (1) and (2) are at work, the amount of $\mathrm{H}_{2} \mathrm{O}_{2}$ generated must be dependent on all the reactants (i.e., $\mathrm{A} \beta, \mathrm{Cu}(\mathrm{II})$, and $\mathrm{O}_{2}$ ). Since in senile plaques the content of $\mathrm{A} \beta$ and concentration of $\mathrm{Cu}(\mathrm{II})$ are high and the function of brains requires a constant supply of large amounts of $\mathrm{O}_{2}(61)$, one would expect that $\mathrm{H}_{2} \mathrm{O}_{2}$ concentration be substantially high. In addition to metabolic degradation of species that can potentially generate ROS and scavenging of $\mathrm{ROS}$ (including $\mathrm{H}_{2} \mathrm{O}_{2}$ ) by antioxidants, we think that the 
slow diffusion of $\mathrm{O}_{2}$ to the metal center in the $\mathrm{Cu}(\mathrm{II})-\mathrm{A} \beta$ complex should have dramatically hindered the $\mathrm{H}_{2} \mathrm{O}_{2}$ generation. Regarding the dependence of $\mathrm{H}_{2} \mathrm{O}_{2}$ generation on the $\mathrm{A} \beta$ sequence, it is interesting to note that mice do not develop $\mathrm{AD}$ (62) and its $\mathrm{A} \beta$ is mutated at two of the metal binding sites, viz., His-13 and Tyr-10 (replaced by Arg and Phe, respectively). The decreased binding affinity of such a mutated $\mathrm{A} \beta$ towards $\mathrm{Cu}(\mathrm{II})$ leads to a dramatically lower $\mathrm{H}_{2} \mathrm{O}_{2}$ production (37). In the case of familial $A D$, the $A \beta$ is pointmutated, which causes early onset AD. Interestingly, none of the mutations occurs in the metal binding region. These facts strongly suggest the important roles of metal binding and $\mathrm{H}_{2} \mathrm{O}_{2}$ production in the pathogenesis of $\mathrm{AD}$.

During the $\mathrm{CV}$ scan reversal, $\mathrm{A} \beta-\mathrm{Cu}(\mathrm{I})$ molecules that have not been completely oxidized by $\mathrm{O}_{2}$ in solution ( $c f$. thin solid curve in Figure 3 and thick solid curves in Figures 4 and 6), will be reoxidized:

$$
\mathrm{A} \beta-\mathrm{Cu}(\mathrm{I})-\mathrm{e}^{-}=\mathrm{A} \beta-\mathrm{Cu}(\mathrm{II})
$$

The concentration of $\mathrm{A} \beta-\mathrm{Cu}(\mathrm{I})$ depends on the catalytic turnover rate, which is in turn governed by the accessibility of the $\mathrm{A} \beta-\mathrm{Cu}(\mathrm{I})$ complex to oxygen and the oxygen concentration in solution. A declined oxygen level in solution results in the availability of more $\mathrm{A} \beta-\mathrm{Cu}(\mathrm{I})$, which leads to a greater oxidation current during the reverse potential scan (cf. Figure 3). The function of metalloproteins in a biological process involving $\mathrm{O}_{2}$ requires the binding to and activation of diatomic $\mathrm{O}_{2}$ molecules by the metal center(s). Recent studies have captured the $\mathrm{O}_{2}$-containing intermediates $(63,64)$. Similarly, the catalytic reduction of $\mathrm{O}_{2}$ by $\mathrm{A} \beta-\mathrm{Cu}(\mathrm{I})$ also entails the binding of $\mathrm{O}_{2}$ to the copper center. It is conceivable that a longer $\mathrm{A} \beta$ segment will increase the steric hindrance for $\mathrm{O}_{2}$ binding to the copper center and decrease the catalytic turnover rate. This is in accord with our experimental results. Given the slow and gradual development of $\mathrm{AD}$, our contention appears to be plausible.

As stated in previous sections, a prerequisite for the catalytic production of $\mathrm{H}_{2} \mathrm{O}_{2}$ is the reduction of $\mathrm{A} \beta-\mathrm{Cu}(\mathrm{II})$ to $\mathrm{A} \beta-\mathrm{Cu}(\mathrm{I})$ and the subsequent binding of $\mathrm{O}_{2}$. This process would not occur in vitro without a suitable electron donor. However, $\mathrm{A} \beta-\mathrm{Cu}(\mathrm{II})$ complex could be reduced in vivo by redox reactions involving easily oxidizable cellular species (i.e., antioxidants). There exists a wide range of intracellular and extracellular electroactive species and antioxidants, some of which, together with their reduction potentials, are listed in Table 3.

Species whose reduction potentials are more positive than the $\mathrm{A} \beta-\mathrm{Cu}(\mathrm{II})$ reduction potential $(0.280 \mathrm{~V})$ are incapable of reducing $\mathrm{A} \beta-\mathrm{Cu}(\mathrm{II})$. These include some important redox-active neurotransmitters such as dopamine, epinephrine, and norepinephrine. This is interesting, since, to our knowledge, there is no evidence directly linking the appearance of A $\beta$ aggregates or senile plaques to the deficiency of these neurotransmitters. It is a well known fact that another neurodegenerative disease, Parkinson's disease, is directly related to dopamine deficiency and loss of dopaminogenic neurons. The species listed inTable 3 that could (i.e. potentials more negative) reduce the $\mathrm{A} \beta-\mathrm{Cu}(\mathrm{II})$ complex can be classified into three categories: extracelluar species (e.g., ascorbic acid), intracellular redox buffers (e.g., glutathione), and membrane-bound redox species (especially those associated with mitochondria that governs cellular respiratory processes and bioenergetics).

Outside the neuronal cells, reduction of $\mathrm{A} \beta-\mathrm{Cu}(\mathrm{II})$ to $\mathrm{A} \beta-\mathrm{Cu}(\mathrm{I})$ by ascorbic acid and vitamin $\mathrm{B} 12$ is thermodynamically favored (Table 3 ). The reduced $\mathrm{A} \beta-\mathrm{Cu}(\mathrm{I})$ can then catalyze the reduction of oxygen to form hydrogen peroxide. The as-formed hydrogen peroxide can either react further with antioxidants such as ascorbic acid and vitamin B12 or attack cell membrane and other organelles in brain. This certainly will deplete the antioxidants and 
damage the cellular defense system, making the cells vulnerable. To verify that the A $\beta$ $\mathrm{Cu}$ (II) reduction by ascorbic acid is kinetically facile, we acquired CVs of ascorbic acid in the absence and presence of $A \beta-C u(I I)$. As shown in Figure S6, without $A \beta(1-16)$ and $\mathrm{Cu}$ (II) in the solution, an irreversible oxidation peak of ascorbic acid at $c a .0 .42 \mathrm{~V}$ was observed. The irreversible reduction is due to the ring-closure reaction following the ET reaction, as shown in equation (4):

Ascorbic acid $+\mathrm{H}_{2} \mathrm{O}=$ Dehydroascorbic acid $+2 \mathrm{H}^{+}+2 \mathrm{e}^{-}$

When $\mathrm{A} \beta-\mathrm{Cu}(\mathrm{II})$ is present, the addition of an equimolar amount of ascorbic acid did not show the characteristic irreversible ascorbic acid oxidation peak. Only after the addition a few more molar equivalents did the oxidation peak appear in the first potential scan (Figure S6). Interestingly, the peak quickly disappeared in the second scan. When the solution was thoroughly purged, the ascorbic acid oxidation peak was observable regardless of the presence of $\mathrm{A} \beta-\mathrm{Cu}(\mathrm{II})$. These observations thus demonstrate that ascorbic acid can rapidly reduce $A \beta-C u(I I)$ to $A \beta-C u(I)$ and the resultant $A \beta-C u(I)$ catalyzes the oxygen reduction. The overall catalytic redox reaction cycle coverts ascorbic acid to dehydroacorbic acid. The rapid depletion of ascorbic acid is also consistent with the high chemical reaction rate constant in the aforementioned kinetic simulation.

There have been many mechanisms suggesting that $A \beta$ penetrates cell membranes and enters cytoplasma (65-67). A $\beta$ has been shown to exist inside $(22,68-70)$ and outside of neuronal cells in AD-affected brains. In PC12 cells and human fibroblasts A $\beta$ oligomers were found to adsorb onto the cell surface and became internalized into the cytosol $(71,72)$. Given the relatively high binding affinity of $\mathrm{A} \beta$ to $\mathrm{Cu}$ (II) (29), $\mathrm{Cu}$ (II)-bound $\mathrm{A} \beta$ monomers and oligomers should be capable of penetrating the neuronal cell membrane. In addition, it is purported that APP from which A $\beta$ is cleaved can function as a copper chaperone, regulating the intracellular copper concentration and homeostasis (73). Inside the neuronal cells, the glutathione redox couple (GSH/GSSG), present at millimolar concentrations, has a high redox buffering capacity. The GSH/GSSG couple not only maintains the function of mitochondria (74) but also regulates the apoptosis of cells (75-79). From Table 3, the reduction of $\mathrm{A} \beta-\mathrm{Cu}(\mathrm{II})$ complex to $\mathrm{A} \beta-\mathrm{Cu}(\mathrm{I})$ by glutathione is favored thermodynamically and $\mathrm{H}_{2} \mathrm{O}_{2}$ produced via Reaction (2) could consequently disrupt the potentiation of the GSH/GSSG couple. The possible decline in the cellular glutathione may not only induce abnormal apoptosis but also cause dysfunction of mitochondria. Another intracellular species whose reduction potential is lower than $\mathrm{A} \beta-\mathrm{Cu}(\mathrm{II})$ complex is pyruvate, which serves as the fuel for mitochondria-mediated metabolic process. As shown by the potential values in Table 3, a redox reaction between $\mathrm{A} \beta-\mathrm{Cu}(\mathrm{II})$ and pyruvate is possible. Similarly, given the presence of a high concentration of $\mathrm{O}_{2}$ in brain and particularly in neuronal cells (61), the catalytic reduction of $\mathrm{O}_{2}$ to $\mathrm{H}_{2} \mathrm{O}_{2}$ by $\mathrm{A} \beta-\mathrm{Cu}(\mathrm{I})$ is likely to occur. The $\mathrm{H}_{2} \mathrm{O}_{2}$ would subsequently oxidize more pyruvate molecules and cause a depletion of the cellular pyruvate concentration. As a result, ATP production is decreased and mitochondria are starved energetically. This p rocess may have some relevance to the observed decline in the production of ATP in AD patients (80-83). In line with our suggestion, therapeutic treatments of $\mathrm{AD}$ patients with pyruvate derivatives have shown promises in alleviating $\mathrm{AD}$ symptoms (84).

It has been well documented that mitochondrial insufficiencies contribute significantly to the pathophysiology of $\mathrm{AD}$ and mitochondrial dysfunction is also a hallmark of $\mathrm{AD}(80,85-87)$. However, the intricate relationship between $\mathrm{AD}$ and mitochondrial dysfunction awaits further elucidation. $A \beta$ has been found to exist inside mitochondria and deposited on mitochondria membranes in $\mathrm{AD}$ brains $(81,88)$. Recent studies demonstrated that, in the 
presence of $\mathrm{Cu}(\mathrm{II}), \mathrm{A} \beta$ inhibits the activity of cytochrome $c$ oxidase in mitochondria (22-24, 82). This provides a possible link between the dysfunction of mitochondria and $\mathrm{A} \beta-\mathrm{Cu}(\mathrm{II})$. The function of mitochondria relies on the uninterrupted ET processes in the cascade of events at the membrane and in the intermembrane space. As shown in Table 3, the redox reactions of $\mathrm{A} \beta-\mathrm{Cu}(\mathrm{II})$ with nicotinamide adenine dinucleotide (NADH), flavin mononucleotide $\left(\mathrm{FMNH}_{2}\right)$, flavin adenine dinucleotide ( $\left.\mathrm{FADH} 2\right)$, Coenzyme $\mathrm{Q}\left(\mathrm{CoQH}_{2}\right)$, cytochrome $b$, cytochrome $c_{1}$ and cytochrome $c$ in the ET chain are all thermodynamically allowed. If there is a reaction of $\mathrm{A} \beta-\mathrm{Cu}(\mathrm{II})$ with any of the species, the normal electron flow will be side-tracked, leading dysfunction of mitochondria and triggering a mitochondrial death pathway. We should note that mitochondrial dysfunction has been shown to be associated with the $\mathrm{AD}$ development $(80,85,86,89)$.

Overall, $\mathrm{A} \beta-\mathrm{Cu}(\mathrm{II})$ complex can react with redox-active molecules essential to neuronal cells and present in biological fluids. Thus, the accurate measurements of the redox potentials of various $A \beta-C u(I I)$ species and the confirmation of $\mathrm{H}_{2} \mathrm{O}_{2}$ generation by $A \beta-$ $\mathrm{Cu}(\mathrm{I})$ complex provides new insight into $\mathrm{AD}$ pathogenesis and offers some possible interpretations about certain $\mathrm{AD}$ symptoms and the roles of metal ions in $\mathrm{AD}$ neuropathology.

\section{CONCLUSIONS}

We have studied, for the first time, the interaction of $\mathrm{A} \beta$ with $\mathrm{Cu}(\mathrm{II})$ by high-resolution mass spectrometry. It reveals that $\mathrm{Cu}(\mathrm{II})$ coordinates with $\mathrm{A} \beta$ in a 1:1 ratio. Independent of the methionine residue, the oxidation state of the copper center in the complex is $2+$. The presumed reduction reaction of $\mathrm{Cu}(\mathrm{II})$ center to $\mathrm{Cu}(\mathrm{I})$ cannot occur in vitro. The redox chemistry of the complexes of $\mathrm{A} \beta(1-16), \mathrm{A} \beta(1-28)$, or $\mathrm{A} \beta(1-42)$ with $\mathrm{Cu}(\mathrm{II})$ was systematically investigated by cyclic voltammetry and the redox potential for the reduction of the copper center was determined to be $0.08 \mathrm{~V}$ (vs. $\mathrm{Ag} / \mathrm{AgCl}$ ). The $\mathrm{A} \beta-\mathrm{Cu}(\mathrm{I})$ electrogenerated was found to catalyze the reduction of oxygen and produce hydrogen peroxide. The remarkable similarity among the voltammetric behaviors of these three complexes excludes the possibility that methionine- 35 can be oxidized by the $\mathrm{Cu}$ (II) center. In addition, we found that the diffusion of oxygen to the $\mathrm{Cu}$ (II) center is dependent on the peptide length (steric hindrance) and hydrophobicity. To our knowledge, this is the first work showing that $\mathrm{A} \beta-\mathrm{Cu}(\mathrm{I})$ can be controllably generated and studied in the presence and absence of $\mathrm{O}_{2}$. The implication of the redox properties of the complex is discussed in the biological context. Based on the redox potentials of $\mathrm{A} \beta, \mathrm{A} \beta-\mathrm{Cu}(\mathrm{II})$ complexes, and common redox-active biomolecules, a number of redox reactions could occur. As a result, antioxidants may be depleted, which may destroy the normal protective system against oxidative stress. Using voltammetry and digital simulation, we show that the thermodynamically allowed reduction of $\mathrm{Cu}(\mathrm{II})-\mathrm{A} \beta(1-42)$ by ascorbic acid, is kinetically facile. The redox reactions of the $\mathrm{A} \beta-\mathrm{Cu}$ (II) complex with species in the ET chain of mitochondria are also thermodynamically favorable. Although whether these reactions occur in vivo remain to be investigated, the possibility raises an important aspect that such reactions could sidetrack the normal electron flow in the respiratory process of mitochondria.

\section{Supplementary Material}

Refer to Web version on PubMed Central for supplementary material. 


\section{Abbreviations}

AD

A $\beta$

ADHP

APP

CV

ESI-FTICR-MS

ET

Met-35

MS

ROS

Tyr-10
Alzheimer's disease

$\beta$-amyloid

10-acetyl-3,7-dihydroxyphenoxazine

Amyloid precursor protein

Cyclic voltammetry

Electrospray ionization-Fourier transform ion cyclotron mass spectrometry

Electron transfer

Methionine at position 35

Mass spectrometry

Reactive oxygen species

Tyrosine at position 10

\section{REFERENCES}

1. Kang J, Lemaire HG, Unterbeck A, Salbaum JM, Masters CL, Grzeschik KH, Multihaup G, Beyreuther K, Muller-Hill B. Amyloid production secretase. Nature. 1987; 325:733-736. [PubMed: 2881207]

2. Masters CL, Simms G, Weinman NA, Multhaup G, McDonald BL, Beyreuther K. Amyloid plaque core protein in alzheimer disease and down syndrome. PNAS. 1985; 82:4245-4249. [PubMed: 3159021]

3. Glenner GC, Wong CW. Alzheimer's disease: initial report of the purification and charaterization of a novel cerebrovascular amyloid protein. Biochem. Biophys. Res. Commun. 1984; 120:885-890. [PubMed: 6375662]

4. Hardy JA, Higgins GA. Alzheimer's disease: the amyloid cascade hypothesis. Science. 1992; 256:184-185. [PubMed: 1566067]

5. Hensley K, Hall N, Subramaniam R, Cole P, Harris M, Aksenov M, Aksenova M, Gabbita P, Wu JF, Carney JM, Lovell M, Markesbery WR, Butterfield DA. Brain regional correspondence between Alzheimer's disease histopathology and biomarkers of protein oxidation. J. Neurochem. 1995; 65:2146-2156. [PubMed: 7595501]

6. Smith CD, Carney JM, Starke-Reed PE, Oliver CN, Stadtman ER, Floyd RA, Markesbery WR. Excess brain oxidation and enzyme dysfunction in normal aging and Alzheimer' disease. PNAS. 1991; 88:10540-10543. [PubMed: 1683703]

7. Lyras L, Cains NJ, Jenner A, Jenner P, Halliwell B. An assessment of oxidative damage to proteins, lipids and DNA in brains from patients with alzheimer's disease. J. Neurochem. 1997; 68:20612069. [PubMed: 9109533]

8. Markesbery WR, Carney JM. Oxidative alterations in Alzheimer's disease. Brain Pathol. 1999; 9:133-146. [PubMed: 9989456]

9. Mecocci P, MacGarvey U, Kaufman AE, Koontz D, Shoffner JM, Wallace DC, Beal MF. Oxidative damage to mitochondrial DNA show marked age-dependent increases in human brain. Ann. Neurol. 1993; 34:609-616. [PubMed: 8215249]

10. Mecocci P, MacGarvey U, Beal MF. Oxidative damage to mitochodrial DNA is increased in Alzheimer's disease. Ann. Neurol. 1994; 36:747-751. [PubMed: 7979220]

11. Nitsch RM, Bluztajn JK, Pittas AG, Slack BE, Growdon JH, Wurtman RJ. Evidence for a membrane defect in Alzheimer's disease brain. PNAS. 1992; 89:1671-1675. [PubMed: 1311847] 
12. Svennerholm L, Gottfries CG. Membrane lipids, selectively diminished in Alzheimer's brains, suggest synapse loss as a primary event in early-onset and demyelination in late-onset form. $\mathrm{J}$. Neurochem. 1994; 62:1039-1047. [PubMed: 8113790]

13. Subbarao KV, Richardson JS, Ang LC. Autopsy samples of Alzheimer's cortex show increased peroxidation in vitro. J. Neurochem. 1990; 55:342-345. [PubMed: 2355227]

14. Marcus DL, Thomas C, Rodriguez C, Simberkoff K, Tsai JS, Strafaci JA, Freedman ML. Increased peroxidation and reduced antioxidant enzyme activity in Alzheimer's disease. Exp. Neurol. 1998; 150:40-44. [PubMed: 9514828]

15. Varadarajan S, Yatin S, Aksenova M, Butterfield DA. Review:Alzheimer's amyloid beta-peptideassociated free radical oxidative stress and neurotoxicity. J. Struct. Biol. 2000; 130:184-208. [PubMed: 10940225]

16. Sims NR. Energy metabolism, oxidative stress and neuronal degeneration in Alzheimer's disease. Neurodegeneration. 1996; 5:435-440. [PubMed: 9117559]

17. Beal MF. Mitochondrial dysfunction in neurodegenerative diseases. Biochim. Biophys. Acta. 1998; 1366:211-223. [PubMed: 9714810]

18. Parker WD Jr. Cytochrome c oxidase deficiency in Alzheimer's disease. Ann. NY Acad. Sci. 1991; 640:59-64. [PubMed: 1663716]

19. de La Monte SM, Luong T, Neely TR, Robinson D, Wands JR. Mitochondrial DNA damage as a mechanism of cell loss in Alzheimer's disease. Lab. Invest. 2000; 80:1323-1335. [PubMed: 10950123]

20. Maurer I, Zierz S, Moller HJ. A selective defect of cytochrome c oxidase is present in brain of Alzheimer's disease patients. Neuobiol. Aging. 2000; 21:455-462.

21. Valla J, Bernt JD, Gonzalez-Lima F. Energy hypo metabolism in posterior cingulate cortex of Alzheimer's patients: superficial laminar cytochrome oxidase associated with disease duration. J. Neurosci. 2001; 21:4923-4930. [PubMed: 11425920]

22. Deshpande A, Mina E, Glabe C, Busciglio J. Different conformations of amyloid beta induce neurotoxicity by distinct mechanisms in human cortical neurons. J. Neurosci. 2006; 26:60116018. [PubMed: 16738244]

23. Crouch PJ, Barnham KJ, Duce JA, Blake RE, Masters CL, Trounce IA. Copper-dependent inhibition of cytochrome $\mathrm{c}$ oxidase by abeta requires reduced methionine at residue 35 of the abeta peptide. J. Neurochem. 2006; 99:226-236. [PubMed: 16987248]

24. Crouch PJ, Blake R, Duce JA, Ciccotosto GD, Li Q-X, Barnham KJ, Curtain CC, Cherny RA, Cappai R, Dyrks T, Masters CL, Trounce IA. Copper-dependent inhibition of human cytochrome c oxidase by a dimeric conformer of amyloid-beta. J. Neurosci. 2005; 19:672-679. [PubMed: 15659604]

25. Schlief ML, Craig AM, Gitlin JD. NMDA receptor activation mediates copper homeostasis in hippocampal neurons. J. Neurosci. 2005; 25:239-246. [PubMed: 15634787]

26. Howell GA, Welch MG, Frederickson CJ. Stimulation-induced uptake and release of zinc in hippocampal slices. Nature. 1984; 308:736-738. [PubMed: 6717567]

27. Curtain CC, Ali FE, Smith DG, Bush AI, Masters CL, Barnham KJ. Metal Ions, pH, and cholesterol regulate the interactions of Alzheimer's disease amyloid- $\beta$ peptide with membrane lipid. J. Biol. Chem. 2003; 278:2977-2982. [PubMed: 12435742]

28. Dong J, Atwood CS, Anderson VE, Siedlak SL, Smith MA, Perry G, Carey PR. Metal binding and oxidation of amyloid- $\beta$ within isolated senile plaque cores: Raman microscopic evidence. Biochemistry. 2003; 42:2768-2773. [PubMed: 12627941]

29. Atwood CS, Scarpa RC, Huang X, Moir Robert D, Jones WD, Fairlie DP, Tanzi RE, Bush AI. Characterization of copper interactions with Alzheimer amyloid- $\beta$ peptides: identification of an attomolar-affinity copper binding site on amyloid $\beta_{1-42}$. J. Neurochem. 2000; 75:1219-1233. [PubMed: 10936205]

30. Curtain CC, Ali F, Volitakisi I, Chernyi RA, Norton RS, Beyreuther K, Barrow CJ, Mastersi CL, Bush AI, Barnham KJ. Alzheimer's disease amyloid- $\beta$ binds copper and zinc to generate an allosterically ordered membrane-penetrating structure containing superoxide dismutase-like subunits. J. Biol. Chem. 2001; 276:20466-20473. [PubMed: 11274207] 
31. Kowalik-Jankowska T, Ruta M, Wisniewska K, Lankiewicz L. Coordination abilities of the $1-16$ and $1-28$ fragments of $\beta$-amyloid peptide towards copper(II) ions: a combined potentiometric and spectroscopic study. J. Inorg. Biochem. 2003; 95:270-282. [PubMed: 12818797]

32. Lovell MA, Robertson JD, Teesdale WJ, Campbell JL, Mardesbery WR. Copper, iron and zinc in Alzheimer's disease senile plaques. J. Neurol. Sci. 1998; 158:47-52. [PubMed: 9667777]

33. Nishino S, Nishida Y. Oxygenation of amyloid beta-peptide (1-40) by copper(II) complex and hydrogen peroxide system. Inorg. Chem. Comm. 2001; 4:86-89.

34. Syme CD, Nadal RC, Rigby SEJ, Viles JH. Copper binding to the amyloid-beta peptide associated with Alzheimer's disease. J. Biol. Chem. 2004; 279:18169-18177. [PubMed: 14978032]

35. Huang X, Cuajungco MP, Atwood CS, Hartshorn MA, Tyntall JDA, Hanson GR, Stokes KC, Leopold M, Multhaup G, Goldstein LE, Scarpa RC, Saunders AJ, Lim J, Moir RD, Glabe C, Bowden EF, Masters CL, Fairlie DP, Tanzi RE, Bush A. Cu(II) potentiation of Alzheimer's A $\beta$ Neurotoxicity. J. Biol. Chem. 1999; 274:37111-37116. [PubMed: 10601271]

36. Lynch T, Cherny RA, Bush AI. Oxidative processes in Alzheimer's disease: the role of A $\beta$-metal interactions. Exp. Gerontol. 2000; 35:445-451. [PubMed: 10959032]

37. Opazo C, Huang X, Cherny RA, Moir RD, Roher AE, White AR, Cappai R, Masters CL, Tanzi $\mathrm{RE}$, Inetstrosa NC, Bush AI. Metalloenzyme-like activity of Alzheimer's disease beta-amyloid. J. Biol. Chem. 2002; 277:40302-40308. [PubMed: 12192006]

38. Karr JW, Kaupp LJ, Szalai VA. Amyloid- $\beta$ binds $\mathrm{Cu}^{2+}$ in a mononuclear metal ion binding site. J. Am. Chem. Soc. 2004; 126:13534-13538. [PubMed: 15479110]

39. Hou L, Zagorski MG. NMR reveals anomalous copper(II) binding to the amyloid A $\beta$ peptide of Alzheimer's disease. J. Am. Chem. Soc. 2006; 128:9260-9261. [PubMed: 16848423]

40. Atwood CS, Moir RD, Huang X, Scarpa RC, Bacarra NME, Romano DM, Hartshorn MA, Tanzi RE, Bush AI. Dramatic aggregation of Alzheimer $\mathrm{A} \beta$ by $\mathrm{Cu}(\mathrm{II})$ is induced by conditions representing physiological acidosis. J. Biol. Chem. 1998; 273:12817-12826. [PubMed: 9582309]

41. Bott AW. Redox properties of electron transfer metalloproteins. Current Separations. 1999; 18:4754.

42. Fezui Y, Hartley D, Harper J, Khurana R, Walsh D, Condron M, Selkoe D, Lansbury P, Fink AL, Teplow D. An improved meethod of preparing the amyloid $\beta$-protein for fibrillogenesis and neurotoxicity experiments. Amyloid: Int. J. Exp. Clin. Invest. 2000; 7:166-178.

43. Hou L, Kang I, Marchant RE, Zagorski MG. Methionine 35 oxidation reduces fibril assembly of the amyloid A $\beta\left(\begin{array}{lll}1 & \text { 2 }\end{array}\right)$ peptide of Alzheimer's disease. J. Biol. Chem. 2002; 277:40173-40176. [PubMed: 12198111]

44. Fenn JB, Mann M, Meng CK, Wong SF, Whitehouse CM. Electrospray ionization for mass spectrometry of large biomolecules. Science. 1989; 246:64-71. [PubMed: 2675315]

45. Schoneich C, Pogocki D, Hug GL, Bobrowski K. Free radical reactions of methionine in peptides: mechanisms relevant to beta-amyloid oxidation and Alzheimer's disease. J. Am. Chem. Soc. 2003; 125:13700-13713. [PubMed: 14599209]

46. Weng YC, Fan F-RF, Bard AJ. Combinatorial Biomimetics. Optimization of a composition of copper(II) poly-L-histidine complex as an electrocatalyst for $\mathrm{O}_{2}$ reduction by scanning electrochemical microscopy. J. Am. Chem. Soc. 2005; 127:17576-17577. [PubMed: 16351066]

47. Bonomo RP, Conte E, Impellizzeri G, Pappalardo G, Purrello R, Rizzarelli E. Copper(II) complexes with cyclo(L-aspartyl) and cyclo(L-glutamyl-L-glutamyl) derivatives and their antioxidant properties. J. Chem. Soc., Dalton Trans. 1996; 1996:3093-3099.

48. Bonomo RP, Impellizzeri G, Pappalardo G, Purrello R, Rizzarelli E, Tabbi G. Coordinating properties of cyclopeptides. Thermodynamic and spectroscopic study on the formation of copper(II) complexes with cyuclo(gly-his) 4 and cyclo(Gly-His-Gly) 2 and their superoxide dismutase-like activity. J. Chem. Soc., Dalton Trans. 1998; 1998:3851-3857.

49. Bard, AJ.; Faulkner, LR. Electrochemical methods: fundamentals and applications. 2nd ed.. New York: John Wiley \& Sons; 2000.

50. Vestergaard M-D, Kerman K, Saito M, Nagatani N, Takamura Y, Tamiya E. A rapid label-free electrochemical detection and kinetic study of Alzheimer's amyloid beta aggregation. J. Am. Chem. Soc. 2005; 127:11892-11893. [PubMed: 16117499] 
51. Brabec V, Mornstein V. Electrochemical behavior of proteins at graphite electrodes: II electrooxidation of amino acids. Biophys. Chem. 1980; 12:159-165. [PubMed: 17000148]

52. Halliwell B, Gutteridge JMC. Oxygen toxicity, oxygen radicals, transition metals and disease. Biochem. J. 1984; 219:1-14. [PubMed: 6326753]

53. Miura T, Suzuki K, Kohata N, Takeuchi H. Metal binding modes of Alzheimer's amyloid $\beta$-peptide in insoluble aggregates and soluble complexes. Biochemistry. 2000; 39:7024-7031. [PubMed: 10841784]

54. Garzon-Rodriguez W, Yatsimirsky AK, Glabe CG. Binding of $\mathrm{Zn}(\mathrm{II}), \mathrm{Cu}(\mathrm{II})$, and Fe(II) ions to Alzheimer's all peptide studied by fluorescence. Bioorg. Med. Chem. Lett. 1999; 9:2243-2248. [PubMed: 10465554]

55. Varadarajan S, Kanski J, Aksenova M, Lauderback C, Butterfield DA. Different mechanisms of oxidative stress and neurotoxicity for Alzheimers $A \beta(1-42)$ and $A \beta$ (25-35). J. Am. Chem. Soc. 2001; 123:5625-5631. [PubMed: 11403592]

56. Sanaullah, Wilson GS, Glass RS. The effect of $\mathrm{pH}$ and complexation of amino acid functionality on the redox chemistry of methionine and X-ray structure of $\left[\mathrm{Co}(\mathrm{en})_{2}(\mathrm{~L}-\mathrm{Met})\right]\left(\mathrm{ClO}_{4}\right)_{2} \cdot \mathrm{H}_{2} \mathrm{O}$. J. Inorg. Biochem. 1994; 55:87-99. [PubMed: 8051543]

57. Bonomo RP, Impellizzeri G, Pappalardo G, Rizzarelli E, Tabbi G. Copper binding modes in the prion octapeptide PHGGGWGQ, a spectroscopic and voltammetric study. Eur. Chem. J. 2000; 6:4195-4202.

58. Yang W, Jarmillo D, Gooding JJ, Hibbert DB, Zhang R, Willett GD, Fisher KJ. Sub-ppt detection limits for copper ions with Gly-Gly-His modified electrodes. Chem. Comm. 2001; 2001:19821983. [PubMed: 12240250]

59. Solomon EI, Sundaram UM, Machonkin TE. Multicopper Oxidases and Oxygenases. Chem. Rev. 1996; 96:2563-2605. [PubMed: 11848837]

60. Morgan C, Colombres M, Nunez MT, Inestrosa NC. Structure and function of amyloid in Alzheimer's disease. Prog. Neurobiol. 2004; 74:323-349. [PubMed: 15649580]

61. Kandel, ER.; Schwartz, JH.; Jessell, TM. Principles of neural science. New York: McGraw Hill; 2000 .

62. Vaughan DW, Peters A. The structure of neuritic plaque in cerebral cortex of aged rats. J. Neuropathol. Exp. Neurol. 1981; 40:472-487. [PubMed: 7195927]

63. Aboelella NW, Reynolds AM, Tolman WB. Catching copper in the act. Science. 2004; 304:836837. [PubMed: 15131298]

64. Prigge ST, Eipper BA, Mains RE, Amzel LM. Dioxygen binds end-on to mononuclear copper in a precatalytic enzyme complex. Science. 2004; 304:864-867. [PubMed: 15131304]

65. Kayed R, Sokolov Y, Edmonds B, McIntire TM, Milton SC, Hall JE, Glabe CG. Permeabilization of lipid bilayers is a common conformation-dependent activity of soluble amyloid oligomers in protein misfolding diseases. J. Biol. Chem. 2004; 279:46363-46366. [PubMed: 15385542]

66. Arispe NH, Pollard HB, Rojas E. Giant multilevel cation channels formed by Alzheimer's disease amyloid $\beta$-protein $[A \beta p-(1-40)]$ in bilayer membrane. PNAS. 1993; 90:10573-10577. [PubMed: 7504270]

67. Quist A, Doudevsli I, Lin H, Azimova R, Ng D, Frangione B, Kagen B, Ghiso J, Lal R. Amyloid ion channels: a common structural link for protein-misfolding disease. PNAS. 2005; 102:1042710432. [PubMed: 16020533]

68. Dickson DW. Apoptotic mechanisms in Alzheimer neurofibrillary degeneration: cause or effect. J. Clin. Invest. 2004; 111:23-27. [PubMed: 15232608]

69. Oddo, s; Caccamo, A.; Shepherd, JD.; Murphy, MP.; Golde, TE.; Kayed, R.; Meterate, R.; Mattson, MP.; Akbari, Y.; LaFerla, FM. Triple-transgenic model of Alzheimer's disease with plaques and tangles: intracellular $A \beta$ and synaptic dysfuction. Neuron. 2003; 39:409-421. [PubMed: 12895417]

70. Lustbader JW, Cirilli M, Lin C, Xu HW, Takuma K, Wang N, Caspersen C, Chen X, Pollak S, Chaney M, Trinchese F, Liu S, Gunn-Moore F, Lue L-F, Walker DG, Kuppusamy P, Zeiwier ZL, Arancio O, Stern D, Yan SS, Wu H. ABAD directly links A $\beta$ to mitochondrial toxicity in Alzheimer's disease. Science. 2004; 304:448-452. [PubMed: 15087549] 
71. Knauer MF, Soreghan B, Burdick D, Kosmoski J, Glabe CG. Intracellullar accumulation and resistance to degradation of the Alzheimer amyloid A4/ $\beta$ protein. PNAS. 1992; 89:7437-7441. [PubMed: 1502155]

72. Burdick D, Kosmoski J, Knauer MF, Glabe CG. Preferential adsorption, internalization and resistance to degradation of the major isoform of the Alzheimer's amyloid peptide, A $\beta 1-42$, in differentiated PC Cells. Brain Res. 1997; 746:275-284. [PubMed: 9037507]

73. Prohaska JR, Gybina AA. Intracellular copper transport in mammals. J. Nutr. 2004; 134:10031006. [PubMed: 15113935]

74. Koehler CM, Beverly KN, Leverich EP. Redox pathways of the mitochondrion. Antioxid. Redox Signal. 2006; 8:813-822. [PubMed: 16771672]

75. Hiroi MA, Tohru H, Kazuya H, Masashi M, Takao T, Niki E. Regulation of apoptosis by glutathione redox state. Free Radic. Biol. Med. 2005; 38:1057-1072. [PubMed: 15780764]

76. Lora J, Alonso FJ, Segura JA, Lobo C, Marquez J, Mates JM. Antisense glutaminase inhibitions decrease glutathione antioxidant capacity and increase apoptosis. Europ. J. Biochem. 2004; 271:4298-4306. [PubMed: 15511236]

77. Biaglow JE, Lee I, Donahue J, Held K, Mieyal J, Dewhirst M, Tuttle S. Glutathione depletion or radiation treatment alters respiration and induce apoptosis. Adv. Exp. Med. Biol. 2003; 530:153164. [PubMed: 14562713]

78. Biroccio A, Benassi B, Filomeni G, Amodei S, Marchini S, Chiorino G, Rotilio G, Zupi G, Ciriolo MR. Glutathione influences C-Myc-induced apoptosis in M14 human melanoma cells. J. Biol. Chem. 2002; 277:43763-43770. [PubMed: 12226097]

79. Van den Dobbelsteen DJ, Nobel CSI, Schlegel J, Cotgreave IA, Orrenius S, Slater AFG. Rapid and specific efflux of reduced glutathione during apoptosis induced by anti-Fas/APO-1 antibody. J. Biol. Chem. 1996; 271:15420-15427. [PubMed: 8662848]

80. Baloyanis SJ. Mitochondrial alterations in Alzheimer's disease. J. Alzheimer's Dis. 2006; 9:119_ 126. [PubMed: 16873959]

81. Aleard AM, Benard G, Augereau O, Malgat M, Talbot JC, Mazat JP, Letellier T, Dachary-Prigent J, Solaini GC, Rossignol R. Gradual alteration of mitochondrial structure and function by $\beta$ amyloid: importance of membrane viscosity changes, energy deprivation, reactive oxygen species production, and cytochrome c release. J. Bioeneg. Biomem. 2005; 37:207-225.

82. Keil U, Bonert A, Marques CA, Scherping I, Weyermann J, Strosznajder JB, Mueller-Spahn F, Czech C, Pradier L, Mueller WE, Eckert A. Amyloid $\beta$-induced changes in nitric oxide production and mitochondrial activity lead to apoptosis. J. Biol. Chem. 2004; 279:50310-50320. [PubMed: 15371443]

83. Ohta S, Ohsawa I. Dysfunction of mitochondria and oxidative stress in the pathogenesis of Alzheimer's disease. J. Alzheimer's Dis. 2006; 9:155-166. [PubMed: 16873963]

84. Antosh, SC.; Meduri, AJ. U.S. Pat. Appl. Publ. US: 2006. p. 10

85. Gibson GE, Sheu KF, Blass JP. Abnormalities of mitochondrial enzymes in Alzheimer's disease. J. Neural Transm. 1998; 105:855-870. [PubMed: 9869323]

86. de la Monte SM, Wands JR. Molecular indices of oxidative stress and mitochondrial dysfunction occur early and often progress with severity of Alzheimer's disease. J. Alzheimer's Dis. 2006; 9:167-181. [PubMed: 16873964]

87. Zhu X, Smith MA, Perry G, Aliev G. Mitochondrial failures in Alzheimer's disease. Am. J. Alzheim Dis. Dement. 2004; 19:345-352.

88. Yan SD, Xiong W-C, Stern DM. Mitochondrial amyloid-beta peptide pathogenesis or late-phase development? J. Alzheimer's Dis. 2006; 9:127-137. [PubMed: 16873960]

89. Moreira PI, Cardoso SM, Santos MS, Oliveira CR. The key role of mitochondria in Alzheimer's disease. J. Alzheimer's Dis. 2006; 9:101-110. [PubMed: 16873957] 


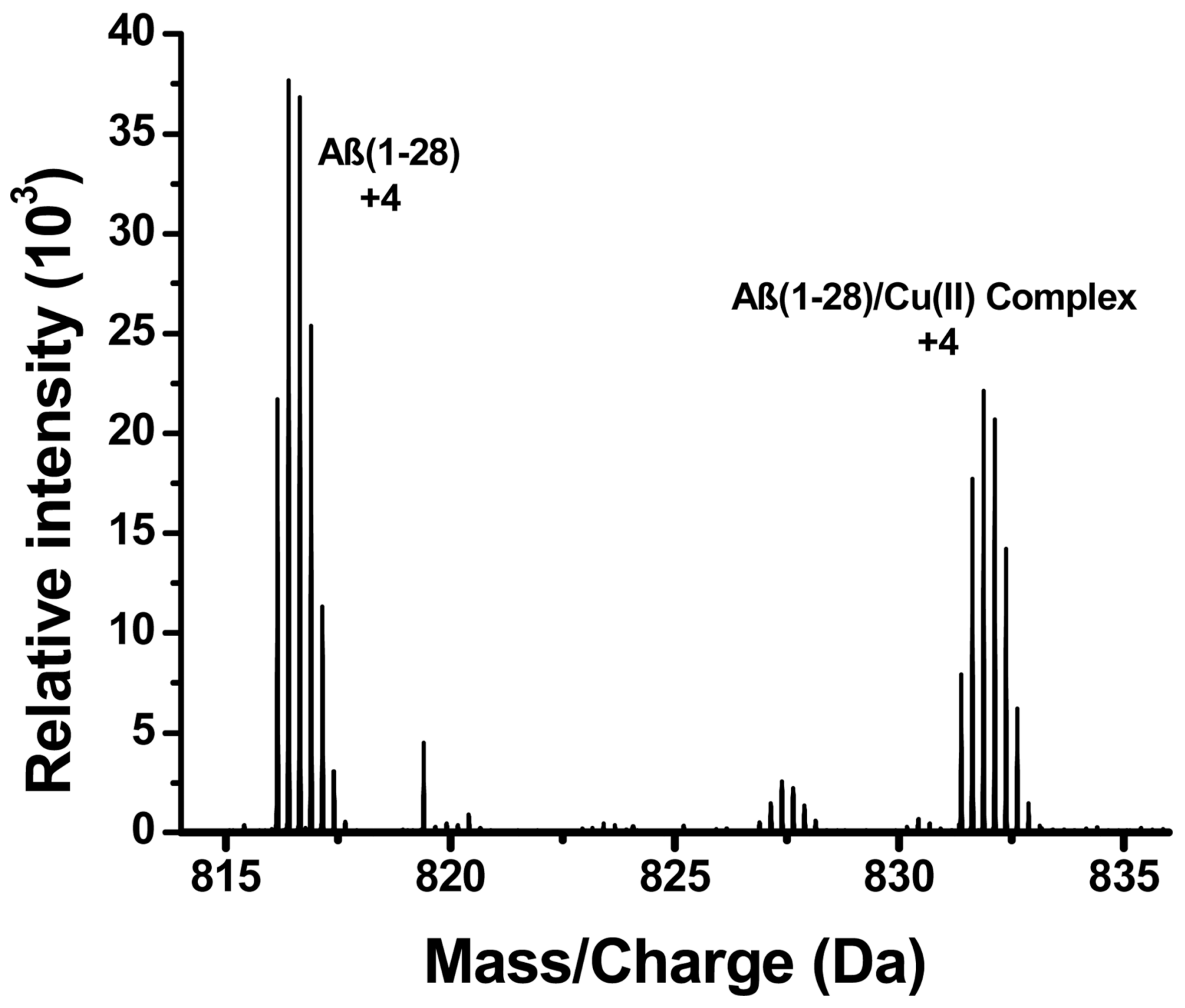

Figure 1.

Positive-ion ESI-MS of an $\mathrm{A} \beta(1-28) / \mathrm{Cu}(\mathrm{II})$ mixture at 1:1 ratio. 


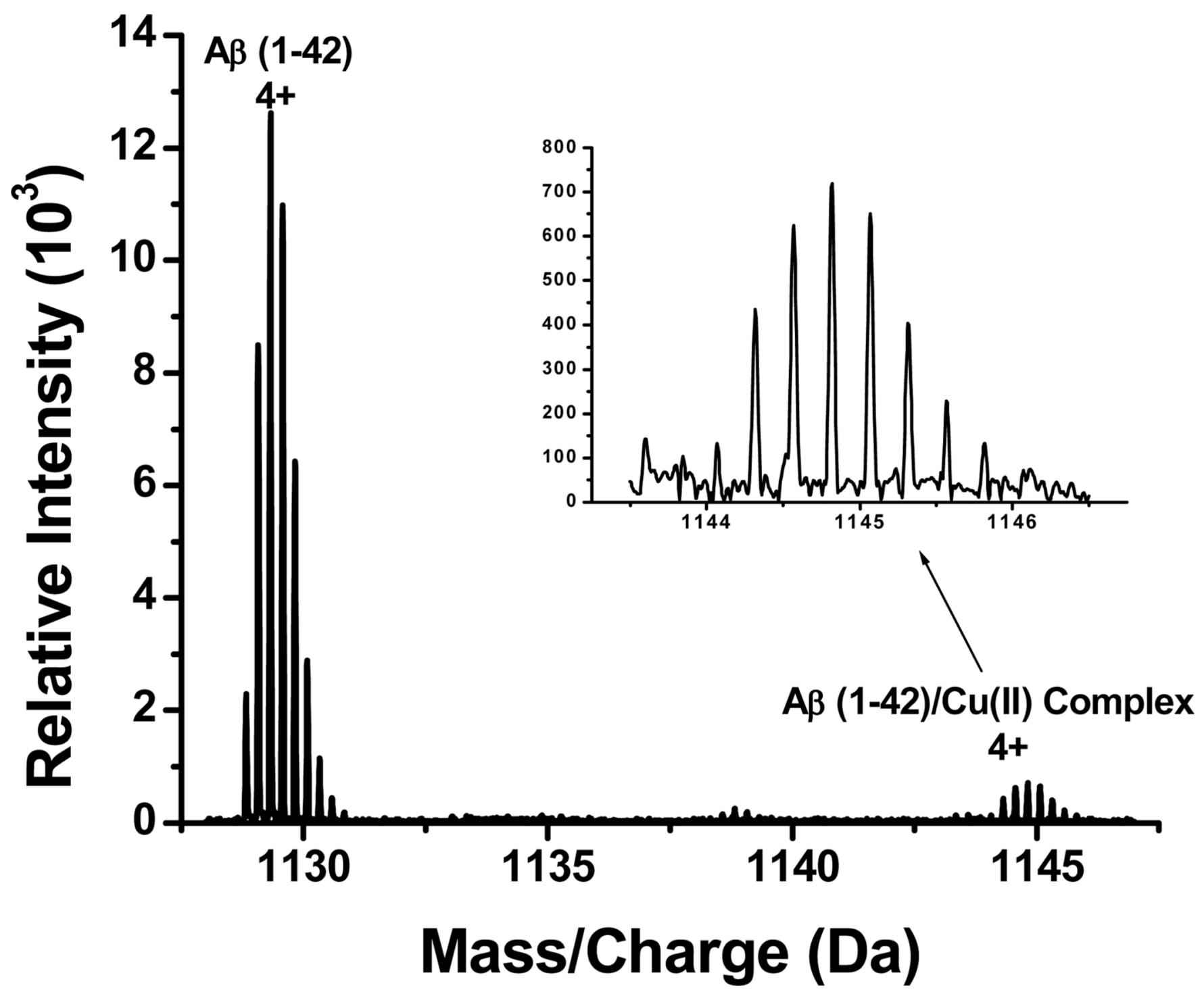

Figure 2.

Positive-ion ESI-MS of an $\mathrm{A} \beta(1-42) / \mathrm{Cu}(\mathrm{II})$ mixture at 1:1 ratio. 


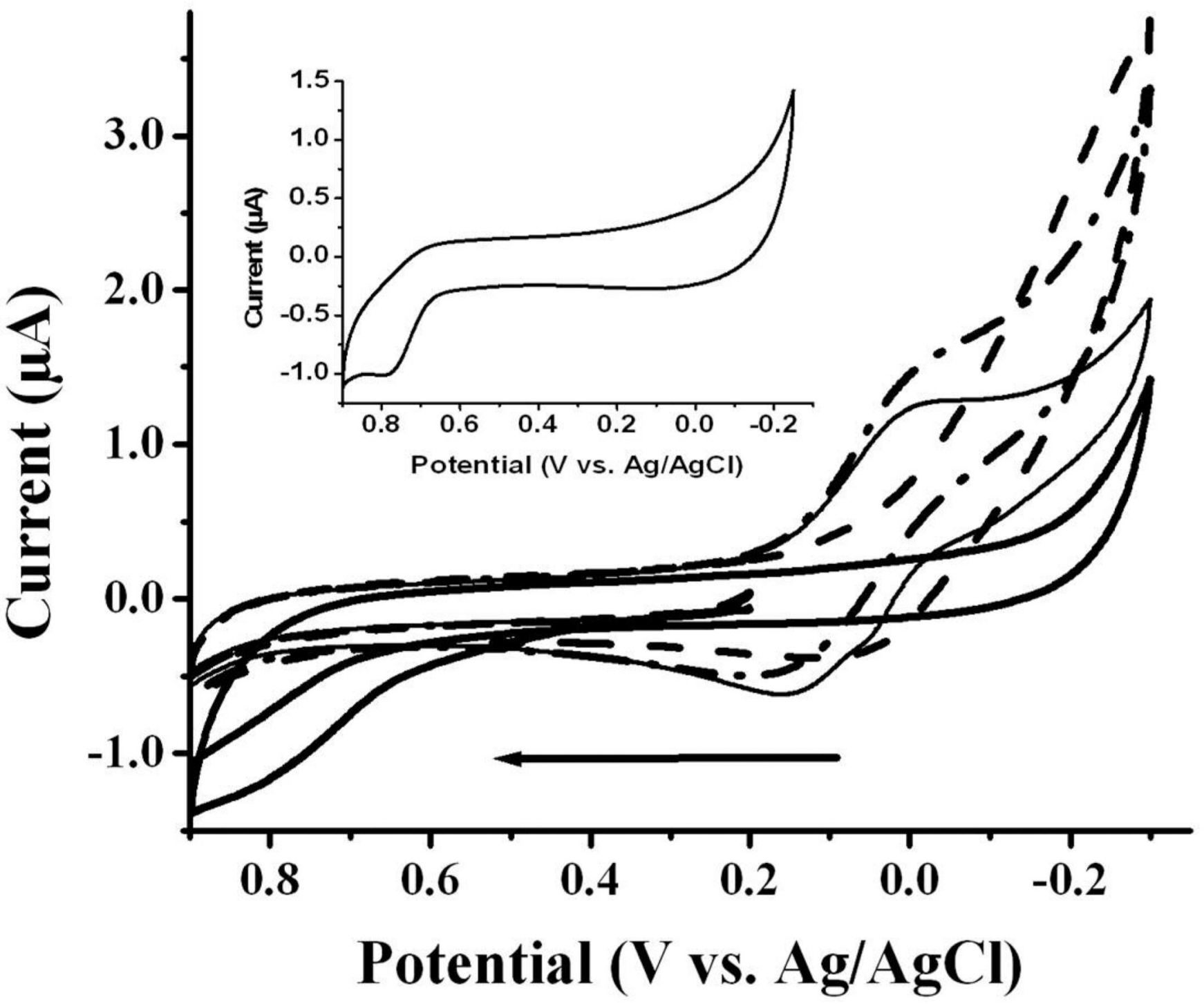

Figure 3.

The cyclic voltammograms of $200 \mu \mathrm{M} \mathrm{A} \beta$ (1-16) (thick solid curve), $100 \mu \mathrm{M} \mathrm{Cu}$ (II) (dashed curve), a mixture containing $200 \mu \mathrm{M} \mathrm{A} \beta$ (1-16) and $200 \mu \mathrm{M} \mathrm{Cu(II)} \mathrm{(thin} \mathrm{solid}$ curve) and an $\mathrm{O}_{2}$-saturated $\mathrm{A} \beta(1-16) / \mathrm{Cu}(\mathrm{II})$ mixture (dash-dot-dash). A voltammogram from a $50 \mu \mathrm{M}$ tyrosine solution is shown in the inset. All solutions were prepared with a buffer containing $5 \mathrm{mM}$ phosphate and $0.1 \mathrm{M} \mathrm{Na}_{2} \mathrm{SO}_{4}(\mathrm{pH} 7.4)$ and data were obtained at a glassy carbon disk electrode with a diameter of $3 \mathrm{~mm}$. The scan rate was $20 \mathrm{mV} / \mathrm{s}$ and the arrow indicates the initial scan direction. 


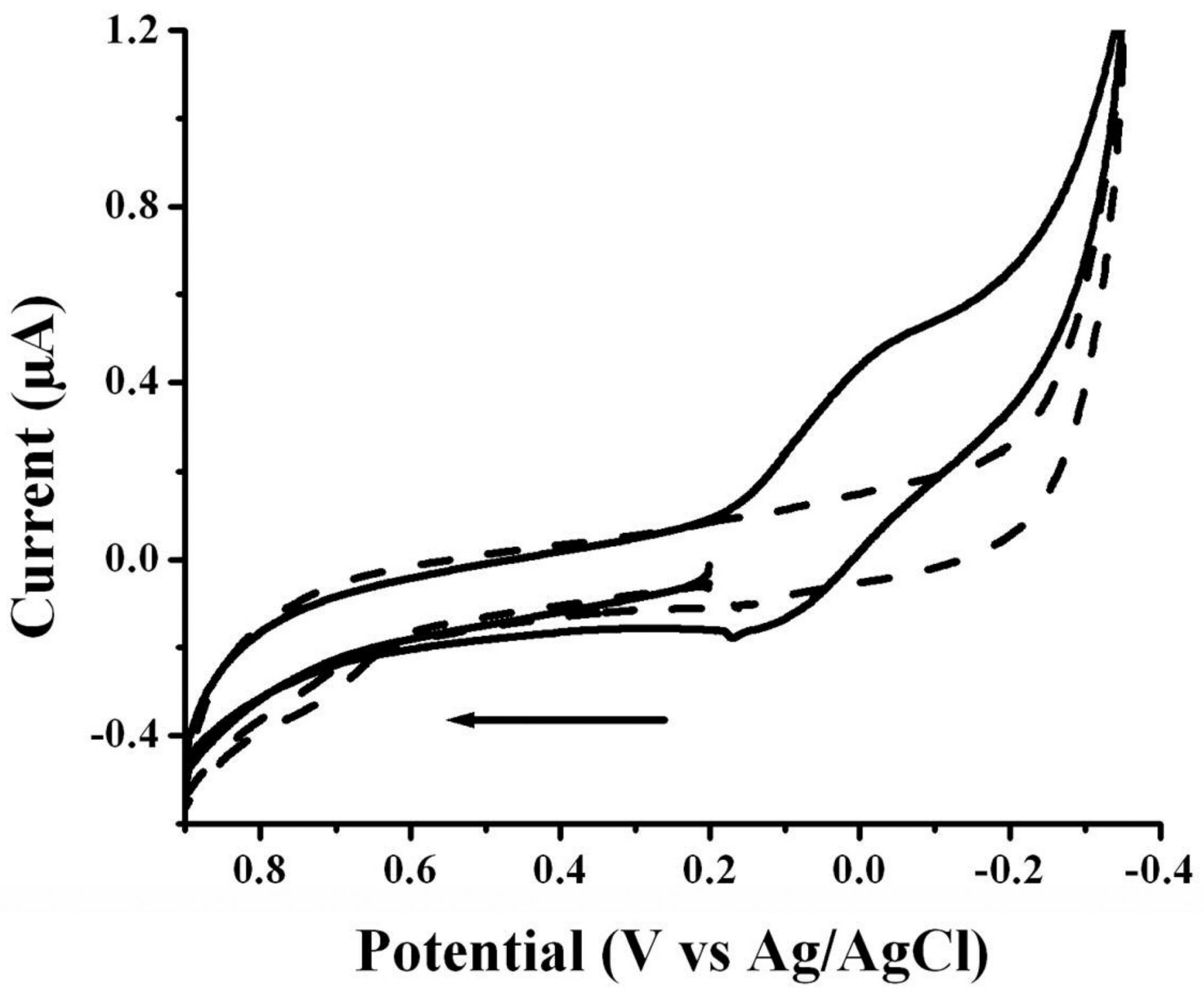

Figure 4.

The cyclic voltammograms of $50 \mu \mathrm{M} \mathrm{A} \beta$ (1-28) (dashed curve) and a mixture of $50 \mu \mathrm{M} \mathrm{A} \beta$ (1-28)/50 $\mu \mathrm{M} \mathrm{Cu}$ (II) mixture (solid curve) acquired at a glassy carbon disk electrode with a diameter of $3 \mathrm{~mm}$ at the scan rate of $20 \mathrm{mV} / \mathrm{s}$. The arrow indicates the scan direction. 


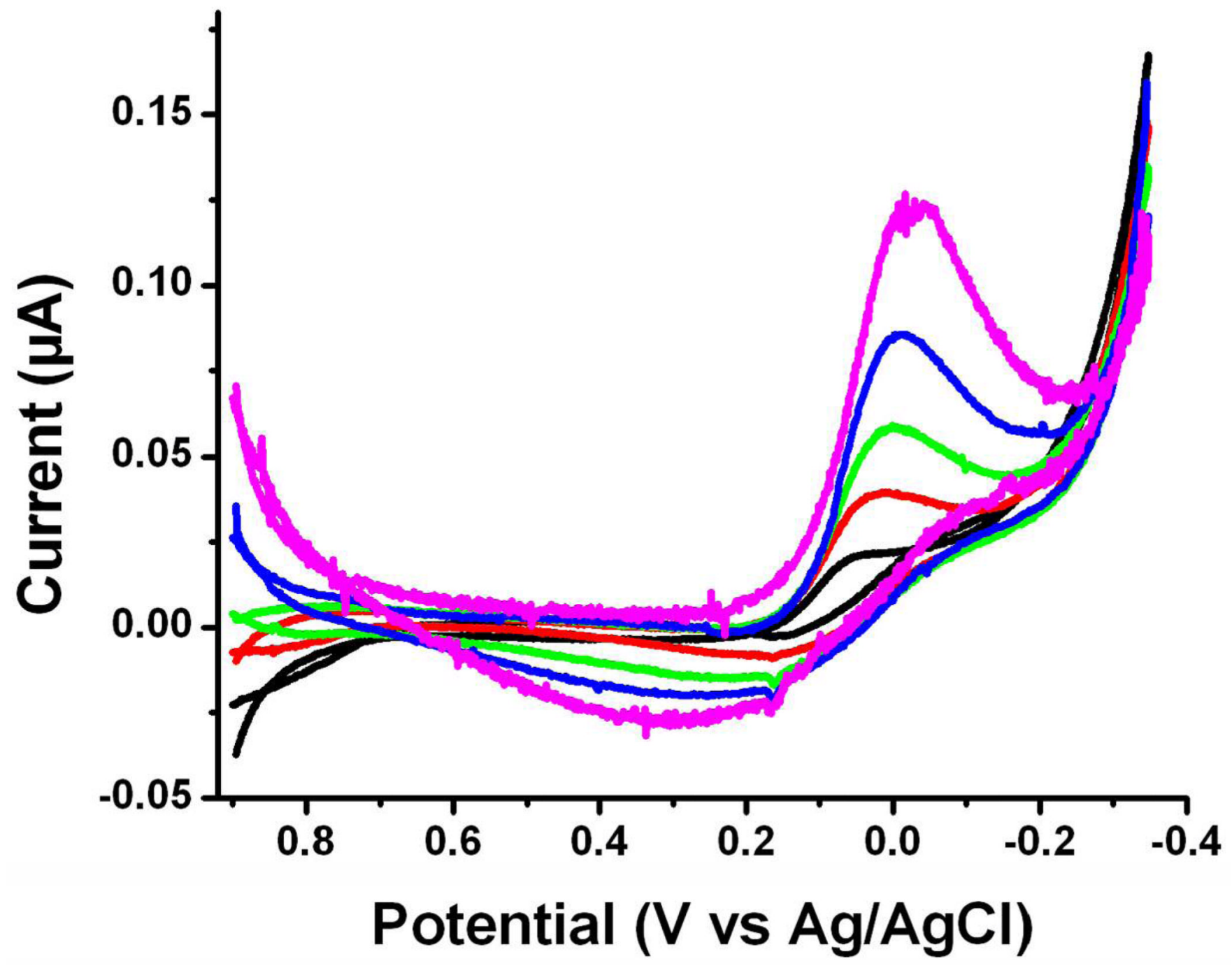

Figure 5.

The cyclic voltammograms generated by subtracting voltammograms of a 1:1 mixture of $\mathrm{A} \beta(1-28) / \mathrm{Cu}(\mathrm{II})$ in a $\mathrm{N}_{2}$-purged solution from those of the same mixture in an air-saturated buffer solution at different scan rates, $0.01 \mathrm{~V} / \mathrm{s}$ (black), $0.02 \mathrm{~V} / \mathrm{s}$ (red), $0.04 \mathrm{~V} / \mathrm{s}$ (green), 0.08 $\mathrm{V} / \mathrm{s}$ (blue) and $0.16 \mathrm{~V} / \mathrm{s}$ (purple). A glassy carbon disk electrode with a diameter of $3 \mathrm{~mm}$ was used as the working electrode. 


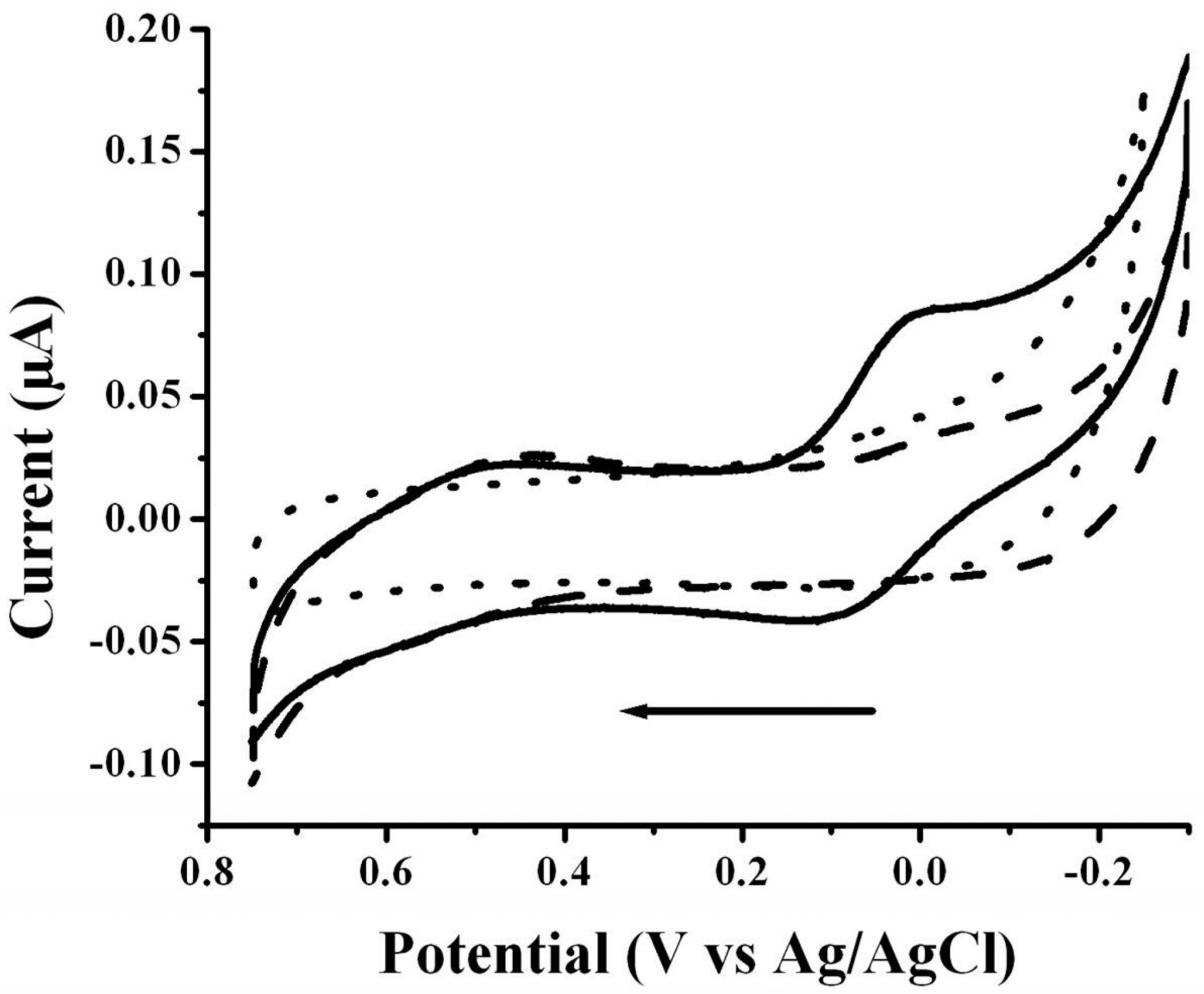

Figure 6.

Cyclic voltammograms of $50 \mu \mathrm{M} \mathrm{A} \beta$ (1-42) (dashed curve) and a mixture of $50 \mu \mathrm{M} A \beta$ (142 ) and $50 \mu \mathrm{M} \mathrm{Cu}(\mathrm{II})$ (solid curve) in a $5 \mathrm{mM}$ phosphate buffer containing $0.1 \mathrm{M} \mathrm{Na}_{2} \mathrm{SO}_{4}$ and $10 \%$ dimethylsulfoxide or DMSO (pH 7.4). The background voltammogram was collected from the same electrolyte solution without $\mathrm{A} \beta(1-42)$ and $\mathrm{Cu}(\mathrm{II})$ (dotted curve). A glassy carbon disk electrode with a diameter of $3 \mathrm{~mm}$ was used as the working electrode. The scan rate was $20 \mathrm{mV} / \mathrm{s}$. 


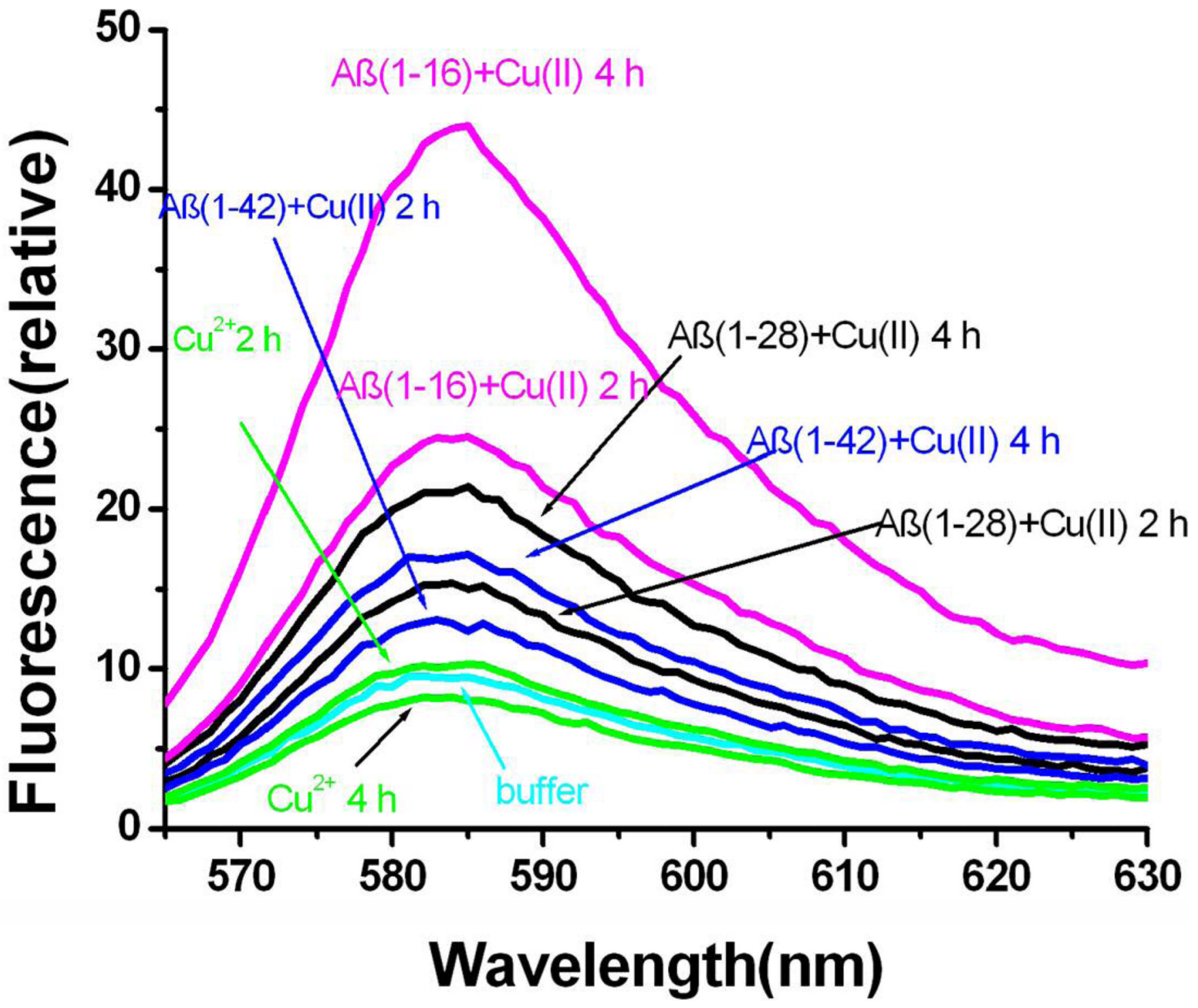

Figure 7.

The fluorescence spectra of resorufin for mixtures containing $\mathrm{Cu}(\mathrm{II})$ and different $\mathrm{A} \beta$ species upon electrolyses for different times: $100 \mu \mathrm{M} \mathrm{A} \beta(1-16) / \mathrm{Cu}(\mathrm{II})$ (pink curves), 100 $\mu \mathrm{M} \mathrm{A} \beta$ (1-28)/Cu(II) (black curves), $50 \mu \mathrm{M} \mathrm{A} \beta(1-42) / \mathrm{Cu}$ (II) (blue curves), $100 \mu \mathrm{M} \mathrm{Cu}$ (II) solution (green curves) and buffer solution (light blue). In the electrolyses, a normal threeelectrode system was used and a glassy carbon working electrode with an area of $0.071 \mathrm{~cm}^{2}$ was held at $0.07 \mathrm{~V}$. The solution volume for each was $300 \mu \mathrm{L}$. The electrolysis times are indicated next to the respective curves. 
Table 3

Redox potentials of $\mathrm{A} \beta-\mathrm{Cu}(\mathrm{II})$ complex and common redox species of biological relevance.

\begin{tabular}{|c|c|}
\hline System & $\mathbf{E}^{0^{\prime}}(\mathrm{V}$ vs NHE$)$ \\
\hline Norepinephrine & $0.384^{(1)}$ \\
\hline Epinephrine & $0.372^{(1)}$ \\
\hline Dopamine & $0.370^{(2)}$ \\
\hline $\mathrm{O}_{2} / \mathrm{H}_{2} \mathrm{O}_{2}$ & $0.295^{(4)}$ \\
\hline Cytochrome $a$ & $0.290^{(1)}$ \\
\hline $\mathrm{A} \beta-\mathrm{Cu}(\mathrm{II})$ & 0.280 \\
\hline Cytochrome $c$ & $0.250^{(1)}$ \\
\hline Hemoglobin & $0.152^{(3)}$ \\
\hline $\mathrm{CoQ} / \mathrm{CoQH}_{2}{ }^{a}$ & $0.100^{(1)}$ \\
\hline Ascorbic acid & $0.051^{(3)}$ \\
\hline Cytochrome $b$ & $0.040^{(1)}$ \\
\hline Fumarate/Succinate & $0.031^{(4)}$ \\
\hline Myoglobin & $0.005^{(1)}$ \\
\hline Crotonyl-CoA/Butyryl-CoA & $-0.015^{(4)}$ \\
\hline FMN/FMNH ${ }_{2} b$ & $-0.120^{(1)}$ \\
\hline Oxaloacetate/malate & $-0.166^{(4)}$ \\
\hline Pyruvate/lactate & $-0.185^{(4)}$ \\
\hline Glutathione & $-0.228^{(1)}$ \\
\hline Vitamin B12 & $-0.244^{(1)}$ \\
\hline $\mathrm{NAD}^{+} / \mathrm{NADH}^{c}$ & $-0.320^{(1)}$ \\
\hline FAD/FADH ${ }_{2}{ }^{d}$ & $-0.327^{(1)}$ \\
\hline
\end{tabular}

${ }^{a}$ Coenzyme Q (ubiquinone) oxidized/reduced forms

${ }^{b}$ Flavin mononucleotide oxidized/reduced forms

${ }^{c}$ Nicotinamide adenine dinucleotide oxidized/reduced forms

$d_{\text {Flavin adenine dinucleotide oxidized/reduced forms }}$

(1) G. Dryhurst, K. M. Kadish, F. Scheller, R. Renneberg, Biological Chemistry, Vol. 1, Academic Press, New York, London

${ }^{(2)}$ D. C.-S. Tse, T. Kuwana, Anal. Chem., 50 (1978), 1315.

${ }^{(3)}$ B. E. Conway, Electrochemical Data, Greenwood Press Publisher. New York

${ }^{(4)}$ A. L. Lehninger, D. L. Nelson, M. M. Cox, Principles of Biochemistry, Worth Publishers. New York 